
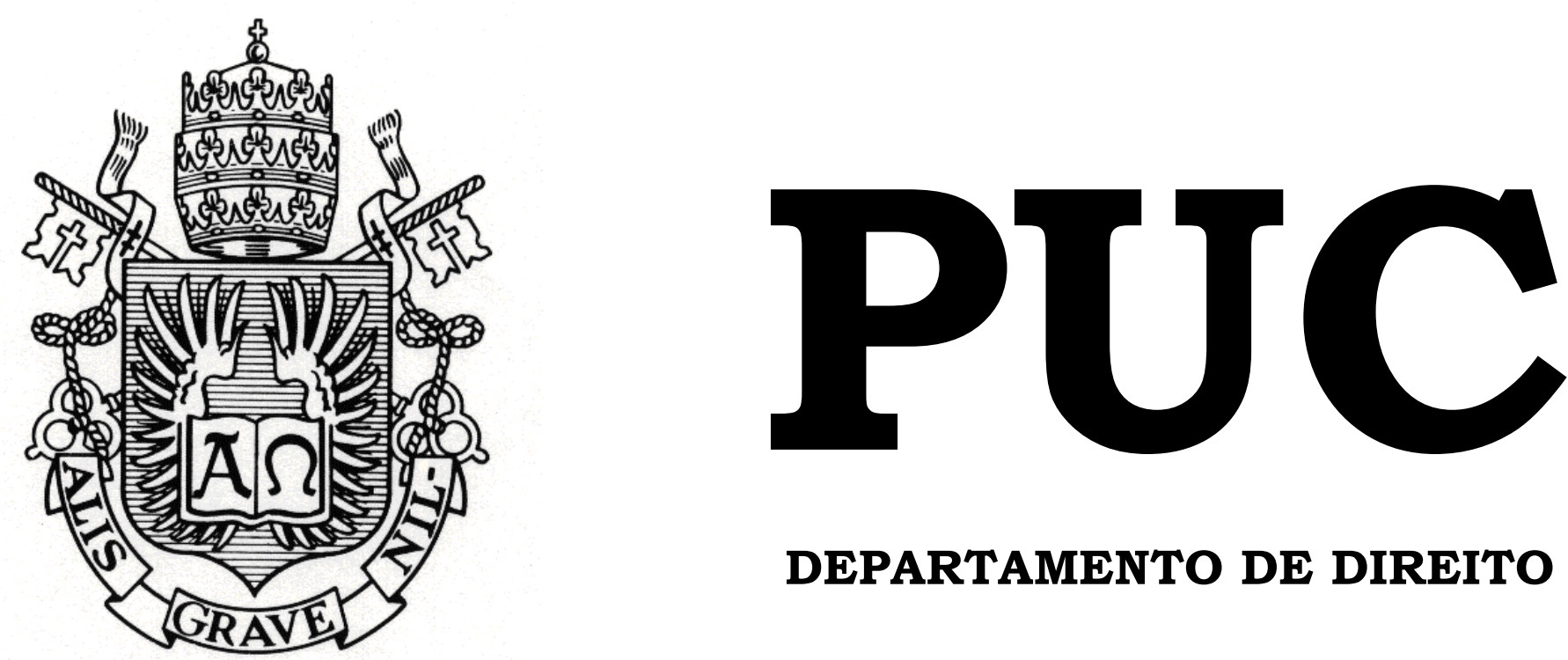

DEPARTAMENTO DE DIREITO

\title{
OS REMÉDIOS PARA O DESCUMPRIMENTO CONTRATUAL NOS DIREITOS INGLÊS E BRASILEIRO
}

por

BÁRBARA NOBRE DE AQUINO

ORIENTADORA: Ana Lucia de Lyra Tavares 2015.1

PONTIFÍCIA UNIVERSIDADE CATÓLICA DO RIO DE JANEIRO RUA MARQUÊS DE SÃO VICENTE, 225 - CEP 22453-900 RIO DE JANEIRO - BRASIL 


\section{OS REMÉDIOS PARA O DESCUMPRIMENTO CONTRATUAL NOS DIREITOS INGLÊS E BRASILEIRO}

por

\section{BÁRBARA NOBRE DE AQUINO}

Monografia

apresentada

ao

Departamento de Direito da Pontifícia Universidade Católica do Rio de Janeiro (PUC-Rio) para a obtenção do Título de Bacharel em Direito.

Orientadora: Ana Lucia de Lyra Tavares 
Dedico este trabalho aos meus pais, que são meu farol e meu porto seguro. 


\section{AGRADECIMENTOS}

Agradeço a Deus por todas as bênçãos e por sempre me proteger e guiar para o melhor caminho.

Agradeço aos meus pais, Erica e Jamir, que sempre encheram minha vida de amor, companheirismo, carinho, apoio e me tornaram quem eu sou hoje. Sem eles eu nada seria.

Aos meus avós, Cacilda e Eric, que são os melhores avós do mundo e sempre foram meus segundos pais, por todo o amor e valiosos ensinamentos.

Ao meu namorado, Gustavo, amor da minha vida e meu melhor amigo, por sempre me apoiar e ajudar em tudo que eu faço.

Ao amigo Eduardo Clarkson, por todo o apoio e por me ter ajudado a iniciar este trabalho.

À minha querida orientadora, Ana Lucia, por toda a atenção e carinho. Poder trabalhar com ela foi uma honra. 


\section{RESUMO}

O objetivo do presente trabalho é servir como guia para os advogados e profissionais que navegam pela área dos contratos internacionais, frequentemente se deparando com elementos de variados ordenamentos jurídicos com os quais nem sempre estão completamente familiarizados. Foi dada ênfase ao Direito Inglês, berço do grandioso sistema da Common Law, por ser um dos sistemas jurídicos que mais corriqueiramente tocam este tipo de contrato. Através de método descritivo, são esclarecidas as principais diferenças e semelhanças entre o Direito Brasileiro e o Inglês quanto aos remédios de que as partes podem se utilizar em decorrência do inadimplemento contratual, tema jurídico basilar, ínsito aos contratos desde suas origens.

Palavras-chave: Direito Comparado - Direito contratual - Direito Inglês - Direito Brasileiro - Contratos Internacionais - Inadimplemento - Remedies - Cláusula Penal - Liquidated Damages. 


\section{SUMÁRIO}

INTRODUÇÃO

CAPÍTULO I - OS SISTEMAS COMMON LAW E ROMANO-

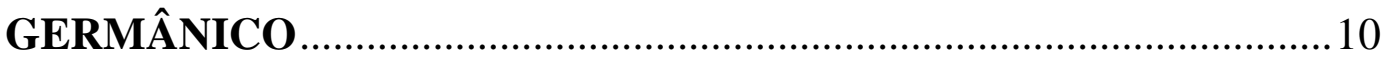

1.1 O Direito Inglês, matriz do sistema de Common Law ........................10

1.2. O Direito Brasileiro, no quadro do sistema Romano-Germânico.....13

1.3. O Direito Contratual nos ordenamentos jurìdicos brasileiro e inglês

CAPÍtUlO II - REMÉDIOS JUDICIAIS PARA O

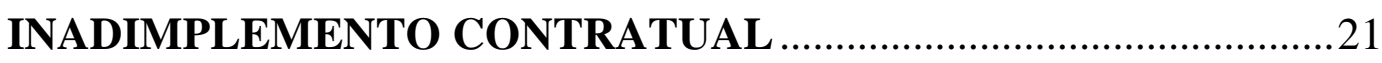

2.1. Specific performance e tutela específica ..............................................21

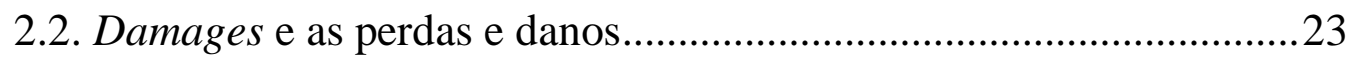

2.2.1. O dever de mitigar o prejuízo .....................................................25

2.2.2. Expectancy, lucros cessantes e a teoria da perda de uma chance 27

2.2.3. Reliance, danos emergentes e a teoria da diferença .......................31

2.3. Restitution e compensatio lucri cum damno.........................................33

\section{CAPÍTULO III - REMÉDIOS CONVENCIONAIS: CLÁUSULAS} CONTRATUAIS SOBRE O DEVER DE REPARAR OS DANOS......37

3.1. Liquidated damages e cláusula penal ...................................................37

3.1.1. Liquidated damages ................................................................ 38

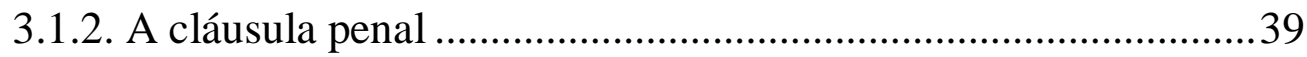

3.2. Cláusulas de exclusão do dever de reparar.........................................46

CAPÍTULO IV - SÍNTESE COMPARATIVA …………………….......56

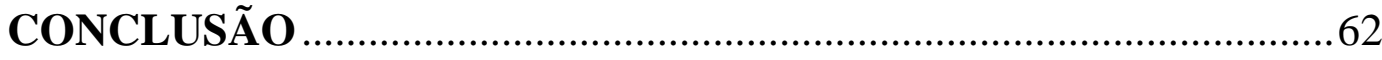

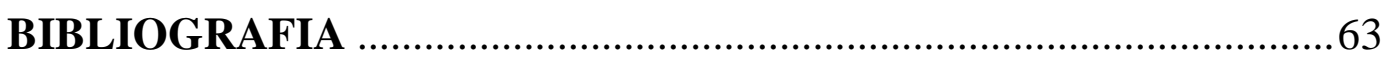


Lista de Tabelas

TABELA 1 - QUADRO COMPARATIVO DOS REMÉDIOS JUDICIAIS E CONVENCIONAIS NOS DIREITOS INGLÊS E BRASILEIRO 58 


\title{
INTRODUÇÃO
}

Em um mundo globalizado, no qual os fluxos comerciais alavancam cada vez mais a celebração de contratos internacionais, torna-se relevante o conhecimento dos sistemas jurídicos estrangeiros, não só para fins de facilitar negociações, mas também porque em contratos internacionais existe a cláusula de escolha de lei aplicável, em que as partes, no exercício de autonomia da vontade, optam pela lei do país que julgam mais adequada àquele negócio jurídico. Esta escolha requer certa cautela, sendo imprescindível que os contratantes conheçam bem a legislação estrangeira para evitar incompreensões e surpresas indesejadas.

Segundo os ensinamentos de Nadia de Araújo:

\begin{abstract}
"Todo contrato internacional será regido por uma lei nacional, determinada pelo Direito Internacional Privado do Estado onde a questão estiver sendo julgada. Ao negociar as cláusulas do contrato internacional é preciso considerar como decidem os tribunais locais." ${ }^{1}$
\end{abstract}

Os contratos internacionais possuem os mesmos elementos formadores que o contrato nacional, mas se diferenciam deste pela presença de um elemento de estraneidade, que os liga a dois ou mais ordenamentos jurídicos. $^{2}$ Tal elemento pode ser a obrigação que deve ser cumprida em outro país, partes domiciliadas no estrangeiro, o local da celebração do contrato, etc.

No Brasil, se entende que a legislação que rege o contrato é aquela do local de sua celebração, nos termos do artigo $9^{\circ}$ da Lei de Introdução ao Direito Brasileiro. ${ }^{3}$ Então, sendo a regra do local em que o contrato foi assinado a ampla autonomia da vontade das partes, poderá ser eleita livremen-

\footnotetext{
${ }^{1}$ ARAÚJO, Nadia de, Direito Internacional Privado: Teoria e Prática Brasileira, p. 384.

${ }^{2}$ Ibid.

${ }^{3}$ Art. $9^{\circ}$ - Para qualificar e reger as obrigações, aplicar-se-á a lei do país em que se constituírem.
} 
te a lei estrangeira que melhor convier ao negócio jurídico. No Brasil, porém, o princípio da autonomia da vontade das partes é bastante restrito, sendo permitido apenas para a arbitragem. Portanto, nosso país não é o lugar ideal para a celebração do contrato, sendo preferível que a assinatura ocorra onde o princípio da autonomia seja consagrado.

A cláusula de lei aplicável trata das questões de direito material dentro do contrato. É possível, inclusive, pela técnica do depeçage, que o contrato seja fracionado, havendo vários ordenamentos jurídicos regendo cada parte.

Dentre todas as opções de sistemas jurídicos estrangeiros, o Direito Inglês com suas peculiaridades e como protótipo da família de Common Law merece especial atenção dos juristas, já que, por ser um sistema muito desenvolvido, principalmente no que tange aos temas comerciais, vastamente debatidos ao longo dos séculos pelos tribunais britânicos, é comumente escolhido para reger os contratos. O sistema inglês, embasado na jurisprudência, é dotado de um dinamismo extremamente caro ao ramo comercial, que colabora e se adéqua bem à celeridade dos fluxos mercantis.

Um dos temas basilares em qualquer contrato são as consequências do inadimplemento das obrigações firmadas pelas partes, preocupação que ronda como uma assombração a vida dos contratantes desde o nascimento do negócio jurídico, nas palavras de Castro Neves ${ }^{4}$.

Os sistemas jurídicos normalmente se preocupam em tratar de forma bem completa o assunto, visando garantir a segurança jurídica, essencial à celebração de compromissos entre as pessoas. Sem qualquer instrumento que garanta o cumprimento do acordado pela outra parte ou ao menos esta-

\footnotetext{
${ }^{4}$ CASTRO NEVES, José Roberto de, Direito das Obrigações, p. 378.
} 
beleça uma justa indenização, a confiança entre as partes ficaria abalada, acarretando um desestímulo à realização de negócios jurídicos. Um cenário que se afigura claramente desfavorável ao crescimento econômico, que depende da celebração de contratos.

Esta monografia, sem a ambição de esgotar o tema, que é de inequívoca importância, focaliza os remédios para o inadimplemento contratual no direito inglês e no direito brasileiro, utilizando-se do método de pesquisa documental para salientar as diferenças e semelhanças mais relevantes nos dois sistemas, a fim que as partes contratantes possam eleger a lei que regerá o contrato cientes dos riscos e responsabilidades que essa escolha pode implicar futuramente, evitando, assim, um possível foco de disputas que venham a prejudicar a relação comercial entre elas.

Destarte, estruturamos o estudo em quatro partes: um primeiro capítulo sobre os sistemas legais brasileiro e inglês dentro do contexto de suas famílias, Romano-Germânica e Common Law, respectivamente, para criar uma base inicial de compreensão do tema pelo leitor; segue-se um capítulo que focaliza o tema específico do estudo, os remédios judiciais para o inadimplemento contratual, ou seja, aqueles que podem ser concedidos ope judicis. No terceiro capítulo examinam-se os remédios convencionais que podem ser estipulados pelas partes no próprio contrato. Nesse mesmo capítulo também são explicitadas as cláusulas que as partes podem inserir com o fim de mitigar ou de eximir-se do dever reparatório. Como final do estudo, incluímos um capítulo sintetizando as principais diferenças e semelhanças do tema dos remédios nos dois sistemas, com um quadro comparativo para melhor visualização. 


\section{CAPÍTULO I - OS SISTEMAS COMMON LAWE ROMANO- GERMÂNICO}

Inicialmente, para a melhor compreensão do presente trabalho, é necessário esboçar uma visão geral do direito inglês, protótipo do sistema da Common Law, e também do sistema pátrio, integrante da família romanogermânica, denominada pelos anglo-saxões, de Civil Law.

\subsection{O DIREITO INGLÊS, MATRIZ DO SISTEMA DE COMMON LAW}

O sistema jurídico da Common Law, construído a partir do século XI na Inglaterra, é fruto de uma longa evolução histórica e baseia-se, sobretudo, no poder do juiz de criação da norma jurídica, o qual, por meio da técnica das distinções, examina se cabe a retomada de uma decisão anterior, o precedente judicial, ou se é o caso de nova decisão. O desenvolvimento da Common Law se deu por fases.

Inicialmente, houve o período anglo-saxônico, em que a ilha da GrãBretanha era povoada por celtas, anglos, saxões e dinamarqueses -, o que se refletia na coexistência de vários direitos locais.

A conquista normanda, em 1066, com a vitória de Guilherme, da Normandia na batalha de Hastings, marca o fim da sociedade tribal e o início do implemento do modelo feudal. Neste período, a Common Law começa a ser esboçada. A lei comum se desenvolveu de um emaranhado de regras costumeiras locais para um sistema de leis comuns aplicadas em todo o país. ${ }^{5}$ Surgem os Tribunais Reais, que julgavam de acordo com a Common Law. Para levar uma questão a esses tribunais, era necessário um writ, uma espécie de formulário, concedido mediante pagamento, que viabilizaria, ou

\footnotetext{
${ }^{5}$ FERNANDES, Paulo Campos e LEITÃO, Walter de Sá, Contratos de Afretamento à Luz dos Direitos Inglês e Brasileiro, p.8.
} 
não, o exame do caso pelos Tribunais Reais. As hipóteses de concessão dos writs, passaram a ser consideradas como tipos de ação que tutelavam o direito subjetivo.. Daí surge o brocado "remedies precede rights", pois, para ter um direito tutelado no Tribunal Real, fazia-se necessário a previsão de um remédio na Common Law. Como ressalta René David, "a cada writ corresponde, de fato, um dado processo que determina a sequência dos atos a realizar, a maneira de regular certos incidentes, as possibilidades de representação das partes, as condições de admissão das provas e as modalidades da sua administração, e os meios de fazer executar a decisão" ${ }^{6}$ O writ era questão preliminar para que a Corte pudesse considerar um remedy a fim de resguardar o direito da parte. ${ }^{7}$ As únicas questões tuteladas pelas cortes do rei, inicialmente, eram as relativas a matérias financeiras (tribunal exchequer), imobiliárias (common pleas) e criminais (king `s bench).

Nesta época, o sistema jurídico era marcado por excessivo formalismo que, muitas vezes, se tornava um obstáculo à solução de conflitos. Nascem, então, com o objetivo de colmatar as lacunas da Common Law, os Tribunais de Chancelaria, que julgavam em equity, buscando a justiça ou fairness nas decisões. Em equity as questões eram levadas ao confessor do rei, o chanceler. Importante destacar que a equity surgiu para completar a Common Law, e não para contrariá-la. Daí o brocado "equity follows the Law".

Então, até 1873, havia dois sistemas de tribunais paralelos na Inglaterra: os tribunais reais, que julgavam de acordo com a lei comum (Common Law) e traziam apenas soluções pecuniárias para os litígios (perdas e danos), e os tribunais de chancelaria, que julgavam em equity, podendo de-

\footnotetext{
${ }^{6}$ DAVID, René, Os Grandes Sistemas do Direito Contemporâneo, p.289.

${ }^{7}$ MADRUGA FILHO, Antenor Pereira, A Noção de Contrato na Common Law - Perspectiva Histórica, p.251.
} 
terminar a execução específica da obrigação como solução do conflito. Posteriormente, entre 1873 e 1875 , houve a fusão formal desses tribunais, através dos Judicature Acts. ${ }^{8}$ A partir deste momento, os tribunais ganharam liberdade para aplicar tanto regras de Common Law quanto de equity.

Modernamente, pode-se dizer que a Common Law é um sistema aberto, no qual a questão antecede a regra, podendo ser resolvida através de um precedente ou, na inexistência deste, através de nova legal rule. ${ }^{9}$ A legal rule indica os princípios jurídicos invocados para a tomada da decisão, sendo na ratio decidendi que reside a força vinculante do precedente. A sentença comporta, ainda, outros esclarecimentos fornecidos pelo juiz, mas que não são indispensáveis a sua fundamentação: os obiter dicta, que, por isto mesmo, não são vinculantes. ${ }^{10}$

Para elaborar uma nova legal rule, é utilizado o distinguish ou técnica das distinções, através da qual o juiz analisará o caso concreto visando detectar elementos novos que justifiquem a não aplicação do precedente e criação de nova regra que se aplique à questão. Nessa análise, a razão e o bom senso desempenham papel fundamental, devendo o magistrado considerar em sua ponderação qual seria o comportamento razoável exigível de pessoas justas e leais naquela situação. Então, o direito na Common Law é criado pelos juízes na prática processual. O juiz cria o direito ou retoma, sob certas condições, decisões judiciais precedentes. A este respeito, destaca Atiyah:

\footnotetext{
"A flexibilidade que esta postura individualista do juiz confere ao sistema é, na verdade, temperada com a imposição de sólidos padrões morais e racionais que, efetivamente, conferem coesão e equilíbrio ao sistema. O estabelecimento da
}

\footnotetext{
${ }^{8}$ FERNANDES, Paulo Campos e LEITÃO, Walter de Sá, loc. cit.

${ }^{9}$ TAVARES, Ana Lucia de Lyra, O Espírito da Common Law e os Contratos, Revista Brasileira de Direito Comparado, 2000, p.38.

${ }^{10}$ Ibid., p.32.
} 
prática de retomada dos princípios que se impuseram para lastrear as decisões básicas anteriores (as ratio decidendi) gerou um todo coerente de normas [...]". ${ }^{11}$

No que tange à organização judiciária no direito inglês, temos a seguinte hierarquia: as cortes superiores são a Câmara dos Lordes, as Cortes de Apelação, a Alta Corte de Justiça e a Corte da Coroa. As cortes inferiores são as Cortes dos Magistrados e as Cortes Locais. ${ }^{12}$ Até 2005, a Câmara dos Lordes se encontrava no topo da hierarquia e suas decisões vinculam as demais cortes. A partir de então, houve a criação de uma Suprema Corte, com poderes de vinculação. A Corte de Apelação se divide em criminal e cível, encontrando-se limitada por decisões da Corte Europeia, da Câmara dos Lordes e por suas próprias decisões anteriores. A sua jurisdição é para apelações de casos julgados na Alta Corte de Justiça ou de Cortes Locais. ${ }^{13}$ A Alta Corte de Justiça se divide em Chancelaria, Corte da Rainha (Queen's Bench Division) e a Divisão de Família. A Corte da Rainha exerce ambos graus de jurisdição, mas é predominantemente uma corte de revisão judicial.

\subsection{O DIREITO BRASILEIRO, NO QUADRO DO SISTEMA ROMANO- GERMÂNICO}

A estrutura do Direito Brasileiro tem raízes na família romanogermânica, marcada pelo apego às leis e codificações. Especialmente na área de Direito Privado, há forte embasamento romano-germânico. Já no Direito Público, nosso ordenamento jurídico sofreu influências do direito norte-americano a partir do período republicano.. Mas, como o foco deste trabalho são os contratos, tema central de direito privado, privilegiaremos o ângulo privatista no exame do tema, embora não desconheçamos a existência de um direito civil constitucional. Contudo, destacaremos os aspectos

\footnotetext{
${ }^{11}$ ATIYAH, Patrick, Law and Modern Society, Oxford University Press, 1989, p.148.

12 FERNANDES, Paulo Campos e LEITÃO, Walter de Sá, loc. cit., p.14.

${ }^{13}$ Ibid., p.16.
} 
estruturais dos sistemas em pauta,, visto que é a estrutura do sistema que nos dá a diretriz sobre a maneira de pensar e organizar o direito. A estrutura do direito pátrio, como já foi dito, é de matriz romano-germânica.

A família romano-germânica tem origem no reestudo do Direito Romano, a partir dos séculos XII e XIII, razão pela qual, como bem assinala René David, uma evolução mais que milenar afastou não só as regras substantivas e de processo, mas também a própria concepção que se tem do direito e da regra do direito, da que era admitida ao tempo de Justiniano. Este sistema jurídico se expandiu para além das fronteiras europeias, especialmente para a América Latina. Tais dimensões se devem tanto à colonização, quanto às facilidades trazidas pela técnica jurídica de codificação. ${ }^{14}$ Com isso, pode-se falar em subgrupos de direitos dentro desta família, diferentemente da Common Law, que, apesar de algumas diferenças naturais nos sistemas dos países que a adotam, ainda guardam inegável unidade.

O surgimento do sistema romano-germânico data do século XII, em meio a uma franca decadência do direito no mundo feudal, quando as universidades europeias, se dando conta da necessidade de regras gerais que fossem além dos limites dos feudos para reger as relações comerciais, retomam os estudos de fragmentos do Direito Romano compilados a mando de Justiniano. Estes acadêmicos, a partir da interpretação do direito dos jurisconsultos romanos, propiciam a criação do sistema romano-germânico, o que marca verdadeiro renascimento do direito.

Esta primeira escola de acadêmicos era integrada pelos glosadores, que procuraram explicar o sentido originário das leis romanas. Com a escola dos pós-glosadores, nos séculos XIV e XV, o direito romano passa a ser expurgado, submetido a distorções. Os juristas não mais se contentam em

\footnotetext{
${ }^{14}$ DAVID, René, loc. cit., p. 25 .
} 
desvendar como era o direito na Roma Antiga, mas põem-se a adaptá-lo às necessidades da sociedade contemporânea. Surge, assim o usus modernus pandectarum. Procura-se, desta forma, encontrar a solução justa para os conflitos, tomando-se em consideração a communis opinio doctorum, ou seja, a opinião dos doutrinadores. ${ }^{15}$

Durante um período essa opinião foi impositiva, até que, a partir dos séculos XVI e XVII, com ápice no XVIII, a Escola do Direito Natural defende ser a razão humana único guia possível para identificação do direito. Cultiva-se, pois, um ideal de universalismo, proclamando-se regras de justiça de um direito universal, imutável e comum a todos os tempos e povos. ${ }^{16}$ Neste mesmo caminho, em 1769, o Marquês de Pombal, em Portugal, faz a Lei da Boa Razão, pela qual a lei só deveria ser aplicada se, pela razão, ela fosse considerada justa. Ocorre a expansão por escrito das normas ideais através da técnica de codificação. Surgem também os ramos do direito. Tudo isso com base na razão.

Destarte, em nosso sistema, têm os códigos e leis papel central. O direito é concebido como norma de conduta geral, com preocupação de justiça e moral. Devido a esse caráter geral, a elaboração das normas tem que seguir critérios que as façam ser um meio termo, nem tão gerais, nem tão específicas. Busca-se que elas não se afastem muito da realidade, mas, ao mesmo tempo, dela não se aproximem tanto a ponto de se tornarem rapidamente obsoletas. Percebe-se que a maneira de pensar em nosso sistema é do geral para o particular, ao passo que na Common Law, o pensamento jurídico é realizado de forma inversa, do particular para o geral.

O papel do juiz no sistema romano-germânico é, basicamente, o de estabelecer qual a legislação aplicável ao caso concreto em pauta. O juiz se

\footnotetext{
${ }^{15}$ Ibid., p.35.

${ }^{16}$ Ibid., p.37.
} 
encontra "amarrado" por uma conjuntura de leis e códigos, dentre os quais ele deve encontrar a solução para o caso. Ele trabalha dentro de uma moldura previamente estabelecida de leis. Para tanto, é essencial que o juiz interprete as normas. Nesta característica, se encontra outro ponto diferencial relativamente ao sistema inglês, em que o juiz, como criador da legal rule no caso concreto, logicamente não passa pelo processo de interpretação da lei. Na Common Law o direito se encontra principalmente na jurisprudência, nos precedentes dotados de força vinculante. Em nosso sistema, a jurisprudência, apesar de ser também fonte de direito, não ocupa papel central e também não é vinculante, dando espaço à lei escrita.

A organização judiciária no Direito brasileiro é regulada pela Constituição Federal nos artigos 92 a 126. Como o Brasil é um Estado federativo, o Poder Judiciário se divide em justiça estadual e federal. A justiça estadual comum é composta, em primeiro grau, por juízes monocráticos e, em segundo grau, pelos tribunais de justiça. Sua competência é residual, podendo julgar as causas que não forem de competência da justiça federal ou especial. A justiça federal comum, por sua vez, é composta por juízes federais, no primeiro grau, e pelos tribunais regionais federais, em segundo grau. Além da justiça comum, temos na esfera federal a justiça especial, que abarca, em primeiro grau, os tribunais regionais do trabalho e eleitoral e, em segundo grau, os tribunais superiores do trabalho, eleitoral e militar. Temos, ainda, dentre os tribunais superiores o Superior Tribunal de Justiça, que resguarda a lei federal e uniformiza o direito nacional infraconstitucional. Por fim, acima de todos os órgãos do Poder Judiciário, encontra-se o Supremo Tribunal Federal, guardião da Constituição Federal, que é a principal norma dentro do ordenamento jurídico brasileiro.

\subsection{O DIREITO CONTRATUAL NOS ORDENAMENTOS JURIDICOS BRASILEIRO E INGLÊS}


O contrato é um negócio jurídico bilateral que se aperfeiçoa pelo encontro das vontades das partes. Havendo consenso, o contrato é celebrado, tornando-se vinculante para as partes. Nele, os contratantes estipulam obrigações a serem cumpridas e, em caso de desobediência, resta a parte infratora inadimplente.

No Brasil, os contratos são regidos por regras gerais presentes no Código Civil de 2002 e alguns tipos de contratos, como o de locação, por leis específicas. Nestes casos, temos contratos típicos, mas também é possível a criação de contratos atípicos, ou seja, aqueles que não possuem uma regulamentação em lei. Ainda assim, deverão ser respeitadas as normas gerais trazidas pelo $\mathrm{CC}$, de acordo com o art.452.

O direito contratual inglês, por sua vez, como já seria de se esperar de um sistema de Common Law, tem na jurisprudência sua principal fonte. Contudo, as questões referentes a cláusulas de exclusão e a disposições leoninas em contratos envolvendo relação de consumo são guiadas mormente pela legislação. ${ }^{17}$ Há também algumas leis que orientam a parte geral dos contratos, como, por exemplo, a Law Reform (Frustrated Contracts) Act de 1934, Unfair Contract Terms Act de 1977, Sale of Goods Act de 1979 e Unfair Terms in Consumer Contracts Regulations de 1999.

Neil Andrews assinala que o direito contratual inglês é reconhecido por sua precisão e estabilidade, sendo comum que empresas estrangeiras adotem a lei inglesa para reger suas transações. ${ }^{18}$

Os contratos são norteados por alguns princípios essenciais, como a liberdade de contratar, a função social e a boa-fé. A liberdade de contratar é reconhecida e prestigiada em ambos os sistemas, desdobrando-

\footnotetext{
${ }_{17}^{17}$ ANDREWS, Neil, Direito Contratual na Inglaterra, p. 32.

${ }^{18}$ Ibid.
} 
se em três ideais: liberdade de contratar ou não, liberdade de escolher com quem contratar e liberdade de escolher o conteúdo a ser contratado. Historicamente, este princípio recebeu ampla dimensão tanto no Brasil quanto na Inglaterra. A autonomia contratual funcionou, por muito tempo, como justificativa da própria justiça contratual. A Escola dos Pandectas, importante movimento de juristas alemães do século XIX, defendia a "onipotência da vontade individual na esfera do direito". A autonomia representava, assim, verdadeiro dogma. ${ }^{19}$ Desta forma, entendia-se pela impossibilidade de intervir no contrato, que seria fruto legítimo da vontade livre das partes.

Esta autonomia contratual exacerbada também foi identificada, classicamente, na Inglaterra. O famoso caso "The Carbolic Smoke Ball" [1892] representou um freio a essa liberdade exagerada. No precedente em questão, uma empresa farmacêutica dizia no anúncio de seu produto, um remédio para gripe, que concederia o prêmio de cem libras para quem, após utilizar o produto por duas semanas, contraísse a doença.

Eis que apresentou-se como fazendo jus ao prêmio anunciado a Sra. Carlill. Para conseguir fazer valer seu direito, Carlill levou o caso às cortes inglesas, que se depararam com um problema, pois, naquela época, vigorava a "will theory", segundo a qual, a vontade interna da parte era suprema. $\mathrm{Na}$ linha desta teoria, a empresa farmacêutica alegou sua intenção com o anúncio era meramente a de se promover, e não a de se vincular ao tal prêmio.

Então, os tribunais ingleses mudaram seu entendimento, trazendo a razoabilidade como forma de temperar a busca pela interpretação da vonta-

\footnotetext{
${ }^{19}$ CASTRO NEVES, José Roberto de, loc. cit., p.61.
} 
de das partes. Buscava-se aferir o conteúdo do contrato pelo que fosse razoável esperar de sua interpretação. ${ }^{20}$

No Brasil, também, a autonomia absoluta da vontade foi sendo cerceada ao longo do tempo, sendo possível a intervenção em caso de violação da função social do contrato ou de normas de ordem pública, por exemplo.

Outro princípio extremamente prestigiado no direito pátrio é o da boa-fé objetiva, que impõe às partes uma conduta transparente, leal, razoável e colaborativa no cumprimento de suas obrigações contratuais. Tal ideal lastreia os contratos não apenas no momento de seu cumprimento, mas também durante as fases pré e pós-contratuais, através dos deveres anexos. Ademais, a boa-fé desempenha papel importante na interpretação dos contratos, como consta no artigo 113 do CC 2002.

A boa-fé também se encontra positivada no artigo 422, segundo o qual as partes devem se guiar pelos princípios de probidade e boa-fé na conclusão e execução do contrato. Pode-se extrair um teor geral da regra trazida pelo CC, o que significa que é à luz do caso concreto que o intérprete deve identificar o comportamento adequado segundo o que seria esperado de homens justos e probos naquela situação.

Os ingleses, na contramão, não têm a boa-fé como princípio explicitamente reconhecido em seu sistema jurídico. As soluções para os problemas concretos de injustiça podem ser encontradas de forma fragmentada ao longo dos precedentes jurisprudenciais. Apesar disso, os ingleses tem uma noção forte de razoabilidade, que sempre lastreia as decisões judiciais, equilibrando o direito contratual.

\footnotetext{
${ }^{20}$ Ibid., p.63.
} 
É essencial notar uma diferença na concepção de contrato na Common Law e no sistema Romano-Germânico: o contrato na visão civilista é baseado historicamente em um princípio de moralidade, segundo o qual o descumprimento da promessa seria um pecado. Este entendimento é concretizado no princípio do pacta sunt servanda, ou seja, o que foi acordado deve ser cumprido. Desta forma, espera-se que a parte cumpra sua palavra, caso contrário, o Estado utilizará sua força para obrigá-la a executar o que fora combinado. Já os ingleses encaram o contrato como uma barganha, então, o que importa, realmente, não é a ideia de que as promessas devem ser cumpridas, mas sim que, por causa desta promessa feita pelo promitente, a contraparte empenhou esforços para entregar uma contraprestação (denominada pelos britânicos de consideration) e não deve sofrer prejuízos com a quebra do contrato. ${ }^{21}$ Esta diferença conceitual explica por quê o remédio preferencial na Civil Law é a execução específica, enquanto na Common Law prioriza-se os damages, como será analisado mais a frente no capítulo sobre os remédios judiciais.

\footnotetext{
${ }^{21}$ DAVID, René, English Law and French Law: A Comparison in Substance - Tagore Law Lectures, p. 126
} 


\section{CAPÍTULO II - REMÉDIOS JUDICIAIS PARA O INADIMPLE- MENTO CONTRATUAL}

Uma das principais formas de extinção dos contratos é através do inadimplemento, que ocorre quando uma das partes deixa de cumprir sua obrigação prevista no contrato ou o faz de forma imperfeita ou defeituosa. A partir deste momento, surge para a parte culpada a responsabilidade contratual, ficando ela obrigada a suportar o ônus respectivo, uma vez que descumpriu um prévio dever específico da relação. ${ }^{22}$ A seguir serão analisadas as principais formas de remediar a inexecução contratual nos sistemas inglês e brasileiro.

\subsection{SPECIFIC PERFORMANCE E TUTELA ESPECÍFICA}

A specific performance (execução específica) é um remédio de $e$ quity de caráter residual, sendo aplicável somente quando os damages, que são o remédio típico de Common Law, não forem adequados para compensar a parte frustrada. Além disso, a specific performance só é admitida em contratos pautados por uma contraprestação (consideration), não sendo aplicável em contratos gratuitos, como a doação. ${ }^{23}$ Consiste em um remédio bastante rígido e penoso, pelo qual se exige do réu o cumprimento da obrigação de fazer previamente ajustada, assegurando, assim, a "lealdade de promessas realizadas". ${ }^{24}$ Este remédio não será deferido se exigir, no caso, o monitoramento por parte do tribunal do cumprimento da atividade. A execução especifica apenas será o principal remedy a ser concedido em dois casos: nos contratos de transferência de imóveis ou direitos reais de propriedade e no contexto das ações em sociedades de capital fechado, pois, como nota Neil Andrews, o objeto contratual é exclusivo.

\footnotetext{
${ }^{22}$ SILVA PEREIRA, Caio Mário da, Instituições de Direito Civil: Volume III, p.325.

${ }^{23}$ ANDREWS, Neil, loc. cit., p.279.

${ }^{24}$ Ibid., p. 277.
} 
Para garantir o cumprimento da decisão do tribunal de equity que ordena a specific performance, determina-se o uso do contempt power, ou seja, aquele que descumprir a obrigação, a partir de tal momento, não apenas será inadimplente perante a outra parte, mas também estará descumprindo ordem judicial, sujeito, portanto, às penalidades decorrentes da dita contempt of Court, que, é importante assinalar, tem caráter punitivo, e não compensatório. ${ }^{25}$

O caráter residual deste remedy se deve a algumas razões importantes. Em primeiro lugar, o juiz guarda uma discricionariedade na concessão da execução específica. Ela deve ser aplicada com parcimônia para que não configure um abuso. Além disso, pelo princípio da mitigação, a parte inocente não pode simplesmente aguardar que o juiz ordene o cumprimento da obrigação $^{26}$, devendo agir positivamente a fim de evitar o agravamento da situação de inexecução contratual. Por fim, é permitido às partes convencionar cláusulas penais e exigir depósitos em garantia como forma de estímulo ao cumprimento da obrigação, sem necessidade da aplicação do remedy da specific performance pelo magistrado.

No caso Co-operative Insurance (1998), Lord Hoffman assinalou que a execução específica seria uma forma de manter as partes num relacionamento hostil, ao passo que a indenização põe fim ao litígio, encerrando a relação jurídica entre elas..

No Brasil, o instituto correspondente ao da specific performance é a tutela específica, prevista no art.461 do Código de Processo Civil:

\footnotetext{
${ }^{25}$ LEHMEN, Alessandra, Specific Performance, p.2.

${ }^{26}$ ANDREWS, Neil, loc. cit.
} 
Art. 461. Na acão que tenha por objeto o cumprimento de obrigacão de fazer ou não fazer, o juiz concederá a tutela específica da obrigacão ou, se procedente o pedido, determinará providências que assegurem o resultado prático equivalente ao do adimplemento.

$\S 1^{0}$ A obrigacão somente se converterá em perdas e danos se o autor o requerer ou se impossível a tutela específica ou a obtenção do resultado prático correspondente.

$\S \mathbf{2}^{\mathbf{0}}$ A indenização por perdas e danos dar-se-á sem prejuízo da multa (art. 287).

Pela leitura do artigo, compreende-se que, em nosso sistema, a execução específica tem caráter principal, diferentemente do que prega o Direito Inglês. Com o inadimplemento contratual, surge o dever primário, que reside no cumprimento da prestação conforme inicialmente devida. O dever secundário, por sua vez, é um substituto, apenas para a hipótese de já não ser possível realizar o dever primário, ou o simples cumprimento do dever primário não representar uma satisfação ou utilidade ao credor. ${ }^{27}$

Ressalta-se que, nas obrigações de fazer personalíssimas, não é possível forçar o devedor a realizar o ato, mas o credor pode tentar estimular o adimplemento com multas ou com a ameaça de cobrar indenização em juízo, o que tornaria extremamente oneroso o descumprimento, como observa José Roberto de Castro Neves ${ }^{28}$.

\subsection{DAMAGES E AS PERDAS E DANOS}

No Direito Brasileiro, não sendo possível o cumprimento in natura, ou seja, a efetuação da obrigação conforme previamente acordada pelas partes, que é a forma preferencial de solução para a relação contratual, resolve-se o contrato em perdas e danos, indenização em pecúnia. Em Common Law, diferentemente, a indenização, intitulada damages, é o remédio prioritário para o inadimplemento. Fazendo jus ao pragmatismo anglo-

\footnotetext{
${ }^{27}$ CASTRO NEVES, José Roberto de, loc. cit., p.325.

${ }^{28}$ Ibid.
} 
saxão, os ingleses vêem como irrazoável a manutenção forçada de uma relação entre as partes que poderia, mais facilmente, ser resolvida com o pagamento de damages à parte frustrada, evitando assim a perpetuação do conflito.

No sistema inglês há também a possibilidade de indenização simbólica para o caso do inadimplemento não causar danos ou o credor não conseguir provar que houve alguma perda. Trata-se de uma indenização de pequeno valor, cuja função é evidenciar que houve um ilícito, sem, contudo, configurar punição do devedor, o que justifica seu baixo valor. ${ }^{29} \mathrm{O}$ credor terá sempre direito a esse valor simbólico no inadimplemento, sendo também incluído no montante da compensação efetiva, quando ficarem provados os danos. Em Ruxley Electronics Ltd v. Forsyth foi determinado que "se a parte não sofrer danos, o que às vezes ocorre, terá direito apenas a uma indenização simbólica. Em qualquer hipótese, a indenização tem por objetivo ressarcir o autor, e não punir o réu." ${ }^{30}$

Caso o credor deseje uma indenização substancial para ressarcir perdas efetivas, ele deverá provar que o descumprimento contratual gerou perdas reconhecidas.

No direito pátrio, por outro lado, o dever de reparar em consequência da falha no cumprimento da prestação apenas pode advir de um dano sofrido pelo credor. Sem dano, não há que se falar em dever de indenizar. Para haver a indenização, deve existir um dano que seja fruto do não cumprimento e este não cumprimento deve ser resultado de causa atribuível ao devedor. ${ }^{31}$ Se do inadimplemento não advier dano, o dever de indenizar será afastado.

\footnotetext{
${ }^{29}$ MCGREGOR, Harvey, McGregor on Damages, cap. 10.

${ }^{30}$ [1996] 1 AC 344, 365, HL.

${ }^{31}$ ROPPO, Enzo, O Contrato, p. 291.
} 
A seguir serão analisadas as formas que os damages podem assumir, os valores abarcados dentro de cada um desses remedies e, também, os institutos correspondentes ou semelhantes no direito pátrio.

\title{
2.2.1. O DEVER DE MITIGAR O PREJUÍZO
}

Quando se fala em indenização, o primeiro ponto importante é o dever do credor de mitigar o prejuízo, ou seja, ele não pode agir de forma a agravar o dever de indenizar do devedor e deve buscar diminuir ao máximo o seu dano. Castro Neves traz o seguinte exemplo:

\begin{abstract}
Um comerciante adquiriu um certo produto para vender em sua loja, mas o fornecedor deixa de entregar a mercadoria (mais grave: ao que tudo indica o comerciante jamais receberá o que ajustou comprar). Esse mesmo comerciante credor do produto, contudo, embora diante do inadimplemento do fornecedor, segue promovendo anúncios da mercadoria que ele, a rigor, não recebeu (nem tampouco receberá). Pois é claro que esses anúncios, onerosos, acabam por majorar os danos sofridos com o inadimplemento do fornecedor. A conduta do comerciante não é razoável. ${ }^{32}$
\end{abstract}

O credor, ao alegar a quebra do contrato, tem o dever de limitar suas perdas e, caso negligencie essa obrigação de mitigar o prejuízo, o devedor pode, inclusive, pedir a redução das perdas e danos proporcionalmente a essa parcela de prejuízo que o credor tinha condições de reduzir.

Este conceito surgiu na Common Law com o "duty to mitigate the loss", que impõe ao autor o dever de tomar todas as medidas razoáveis para mitigar a perda decorrente da violação e o proíbe de reivindicar qualquer valor de perdas e danos que seja decorrente de sua omissão a esse respeito. ${ }^{33} \mathrm{Se}$ os esforços de mitigação tiverem sucesso, a responsabilidade da ré

\footnotetext{
${ }^{32}$ CASTRO NEVES, José Roberto de, loc. cit., p.356.

${ }^{33}$ [1912] AC 673, 689, HL.
} 
será alterada de acordo; porém, se a mitigação falhar, a indenização será reduzida proporcionalmente. ${ }^{34}$

No caso British Westinghouse Co v Underground Electric Railways Co of London Ltd ficou estabelecido que a base fundamental dos damages é a compensação pecuniária naturalmente decorrente da quebra de contrato, qualificada pelo princípio que impõe ao autor da demanda o dever de adotar todas as medidas razoáveis para mitigar a perda decorrente do inadimplemento, o que impede que ele exija qualquer parte dos danos que seja fruto de sua própria negligência em cumprir tal dever. ${ }^{35}$

No Brasil, não há norma expressa sobre o tema, mas seria uma decorrência lógica do dever de lealdade entre as partes imposto pela boa-fé, tão cara em nosso ordenamento jurídico. O credor deve fazer o possível para diminuir os danos causados pela quebra contratual e estará abusando de seu direito de receber indenização caso contribua para o aumento de seu prejuízo. Então, podemos encontrar respaldo para o dever de mitigar no art. 187 do Código Civil. ${ }^{36}$

Se o credor, perante o inadimplemento, contribui para agravar seus danos, o devedor poderá reclamar diminuição no ressarcimento, tendo em vista que o dano sofrido pelo credor terá resultado, ao menos parcialmente, de um ato a ele próprio imputável, como assevera Castro Neves. Mas também pode ocorrer que o credor adote uma medida para mitigar o prejuízo que resulte maléfica, mesmo agindo em boa-fé. Se a opção da parte for razoável, não há violação do dever de mitigar o prejuízo. Já na hipótese de o credor se manter inerte diante da quebra contratual, o caso é mais comple-

\footnotetext{
${ }^{34}$ ANDREWS, Neil, loc. cit., p.297.

${ }^{35}$ [1912] AC 673.

${ }^{36}$ Art.187, CC: "Também comete ato ilícito o titular de um direito que, ao exercê-lo, excede manifestamente os limites impostos pelo seu fim econômico ou social, pela boa-fé ou pelos bons costumes."
} 
xo, pois é difícil saber até que ponto ele de fato poderia mitigar seu dano. Sendo assim, faz-se necessária uma análise do caso concreto para saber se a omissão do credor poderia ser considerada abusiva, não sendo possível oferecer uma resposta prima facie. ${ }^{37}$

No Direito Inglês o Law Reform (Contributory Negligence) Act de 1945 dispõe:

\begin{abstract}
"Sempre que uma pessoa sofrer danos e esses danos forem decorrentes parcialmente da própria culpa e parcialmente da culpa de qualquer outra pessoa, a reivindicação envolvendo tais danos não poderá ser prejudicada por conta da culpa da pessoa que os sofreu. No entanto, o valor do ressarcimento devido em virtude desses danos deve ser reduzido no montante que o juiz considerar justo e equitativo, levando em conta a participação do autor na responsabilidade pelos danos causados."
\end{abstract}

Nos tribunais ingleses também já foi debatida a possibilidade de o credor, na tentativa de mitigar seu prejuízo, acabar lucrando de forma a ser integralmente ressarcido dos danos mediante sua própria conduta. A questão é controversa, havendo precedentes em que os benefícios foram levados em conta e outros em que ficou entendido que os benefícios não guardavam relação suficiente com a violação inicial. ${ }^{38}$

\title{
2.2.2. EXPECTANCY, LUCROS CESSANTES E A TEORIA DA PERDA DE UMA CHANCE
}

Na Common Law o principal remédio em damages é a expectancy (expectativa de lucros futuros ${ }^{39}$ ), que visa colocar a parte frustrada na posição em que ela esperava ficar com o contrato cumprido. Há uma projeção futura da situação em que o credor teria se encontrado fosse o contrato de-

\footnotetext{
${ }^{37}$ CASTRO NEVES, José Roberto de, loc. cit., p.357.

${ }^{38}$ ANDREWS, Neil, loc. cit., p.297.

${ }^{39}$ Os termos utilizados pelo Direito Inglês são aqui livremente traduzidos para o Português, tendo em vista que não é possível fazer uma tradução exata por conta das diferenças de concepções jurídicas entre os dois sistemas legais.
} 
vidamente cumprido. É uma hipótese de "perda de negócio" que se busca remediar, sendo o remédio ideal para a parte frustrada.

Para que o remédio de expectancy seja concedido à parte frustrada, devem estar presentes dois elementos fundamentais: previsibilidade do dano e certeza razoável. É necessário que o devedor tivesse conhecimento de que seu inadimplemento geraria aquele prejuízo ao credor e isso engloba os danos emergentes e lucros cessantes. Além disso, o credor precisa mostrar indícios razoáveis de que teria aquele ganho e deixou de auferi-lo em razão do inadimplemento, não havendo espaço para meras especulações.

O leading case Hadley v. Baxendale $(1854)^{40}$ estabeleceu as diretrizes para a compensação por danos emergentes e lucros cessantes, ditando a regra de que a parte inadimplente responde por todas as perdas que eram previsíveis para os contratantes. No caso em questão, Hadley era um moleiro e uma peça do motor de seu moinho quebrou, necessitando ser enviada a engenheiros para conserto até um dia estipulado. Para cumprir a tarefa de entregar a peça no local onde o conserto seria feito, Hadley contratou Baxendale and Ors, que, no entanto, falhou em cumprir o contratado na data estipulada pelo contratante, causando, assim, a perda de negócios por parte de Hadley, que precisava do moinho funcionando para o desempenho de seu trabalho. O tribunal do júri concedeu ganho de causa ao autor e Baxendale apelou alegando que não sabia que o autor sofreria qualquer dano específico por conta do atraso.

Em grau de apelação, a Corte reformou a decisão do júri, negando a compensação por lucros cessantes a Hadley, sob o fundamento de que Baxendale só poderia ser responsabilizado pelos danos previsíveis de plano ou se Hadley tivesse mencionado essas circunstâncias especiais com antece-

${ }^{40}[1854]$ 
dência. O simples fato de que o contratante está enviando algo para ser consertado não tem como premissa a perda de lucros pelo atraso na entrega do objeto para conserto. Este entendimento é adotado até os dias de hoje tanto na Inglaterra quanto nos Estados Unidos.

No Direito Brasileiro, temos as perdas e danos, que englobam o que o credor perdeu e o que razoavelmente deixou de lucrar, nos termos do artigo 402 do Código Civil. São os danos emergentes e os lucros cessantes. O que mais se assemelha ao instituto da expectancy em nosso sistema é a ideia de lucros cessantes, que são aqueles que o credor lesado razoavelmente deixou de receber em função do descumprimento. São uma projeção, o que o credor deixou de ganhar. ${ }^{41}$

Castro Neves traz o exemplo do taxista que deixa seu táxi em uma oficina para conserto, mas a oficina demora bem mais do que o tempo acordado para entregar o veículo. Além da perda pelo inadimplemento da obrigação de consertar o táxi no dia estabelecido (no que seria o dano emergente), o motorista ficou impedido de circular com o carro, deixando de receber por todo esse tempo (prejuízo qualificado como os lucros cessantes, pois resulta no que o taxista deixou de ganhar). ${ }^{42}$

Os danos emergentes somados ao lucro cessante visam indenizar o credor de forma integral por todo seu prejuízo. É exigido, no entanto, para que o dano seja indenizável, que ele possa ser razoavelmente identificado, não sendo indenizado o dano meramente possível. Nosso ordenamento não tutela meras especulações. Os lucros cessantes devem se basear em dados concretos, não em meras expectativas. Assim, para que a lucro cessante seja indenizado, deve haver prova de que o lucro teria ocorrido, não fosse pelo inadimplemento. Se a prova não for possível, pode-se demonstrar que, pelas

\footnotetext{
${ }^{41}$ CASTRO NEVES, José Roberto de, loc. cit., p. 338.

${ }^{42}$ Ibid.
} 
experiências passadas, o lucro iria fatalmente ocorrer. ${ }^{43}$ Neste sentido, leciona Caio Mário:

As perdas e danos não poderão ser arbitrários. Não pode o credor receber, a esse título, qualquer lucro hipotético. Somente lhe cabe, com fundamento na reparação, receber, como benefício de que o dano o privou, aquilo que efetivamente decorreu do fato imputável, e os lucros cessantes por efeito direto e imediato do descumprimento da obrigação. Era lícito ao credor esperar que a execução da obrigação the proporcionasse um incremento patrimonial, consequente ao acrescentamento econômico que a prestação lhe traria. [...] A reparação das perdas e danos abrangerá, então, a restauração do que o credor perdeu e a composição do que deixou razoavelmente de ganhar, apurando segundo um juízo de probabilidade." 44

Outro aspecto examinado nos dois sistemas analisados decorre da teoria da perda de uma chance, invocada quando não é possível saber-se se o dano ocorreria. Há apenas a perda da chance em garantir um proveito. ${ }^{45}$ Essa teoria se aplica em casos em que alguém possuía uma chance efetiva de adquirir uma vantagem ou de evitar um prejuízo e teve tal chance frustrada em razão da conduta danosa, segundo Caio Mário. Busca-se responsabilizar alguém por ter impedido que uma pessoa consiga atingir um resultado. Não se sabe, de antemão, se o resultado seria atingido, mas o fato é que, pela conduta de uma pessoa, sequer houve a chance de se tentar alcançá-lo. ${ }^{46}$ Aqui, diferentemente dos lucros cessantes, há apenas um certo grau de probabilidade de obtenção de uma vantagem, sendo impossível afirmar que o resultado ocorreria na ausência do inadimplemento. Então, a perda da chance será indenizada não de acordo com o benefício esperado, mas sim com base em percentuais maiores ou menores de probabilidade. ${ }^{47}$

No precedente Allied Maples Group v. Simmons \& Simmons, a Court of Appeal decidiu que não se admite a indenização por perda de uma oportunidade quando a probabilidade de concretização não for "realista" ou

\footnotetext{
${ }^{43}$ Ibid., p.338.

${ }^{44}$ SILVA PEREIRA, Caio Mário da, Instituições de Direito Civil: Volume II, p.317.

${ }^{45}$ CASTRO NEVES, José Roberto de, op.cit., p. 345.

${ }^{46}$ Ibid., p. 346.

${ }^{47}$ SILVA PEREIRA, Caio Mário da, loc. cit., p. 331.
} 
"concreta". ${ }^{48} \mathrm{O}$ autor deve provar que suas chances não eram meramente especulativas. Conseguindo provar isto, a avaliação da chance será levada em conta na quantificação dos danos, tomando como base, de um lado, algo que possa ser considerado real ou concreto e, de outro lado, a quase certeza. A corte entendeu que a delimitação dos limites mínimos e máximos em forma de porcentagem não seria de utilidade, diferentemente do entendimento brasileiro sobre o tema. ${ }^{49}$

Em Jackson v. Royal Bank of Scotland ${ }^{50}$, a House of Lords concedeu indenização por perda de negócio futuro. A autora importava mercadorias do Extremo Oriente para o Reino Unido. O banco violou o contrato ao revelar acidentalmente a um terceiro detalhes sobre a margem de lucro da importadora. Isto ocasionou o cancelamento dos negócios da autora com o comprador final (um atacadista que vendia os produtos no Reino Unido). Os lordes entenderam que o pedido principal não se baseava em mera especulação e, portanto, a autora faria jus à indenização pela perda de receita futura. A extensão desse prejuízo, entretanto, era mera suposição. A indenização foi estimada em um período de quatro anos, representando estimativa aproximada, com o propósito de refletir a percepção de que as operações tenderiam a diminuir gradativamente com o decorrer do tempo ainda que o inadimplemento não tivesse ocorrido. ${ }^{51}$

\subsubsection{RELIANCE, DANOS EMERGENTES E A TEORIA DA DIFEREN-} ÇA

Caso o credor não possua os elementos necessários para obter o remedy de expectancy, ele ainda pode conseguir ter seu prejuízo solucionado através de reliance (confiança). Este remédio, menos eficiente que a expec-

\footnotetext{
${ }^{48}$ ANDREWS, Neil, loc. cit., p.286.

${ }^{49}$ [1995] 1 WLR 1602, CA.

${ }^{50}$ [2005] UKHL 3; [2005] 1 WLR 377, [43].

51 ANDREWS, Neil, loc. cit., p.287.
} 
tancy, visa colocar a parte frustrada na posição em que ela se encontrava antes de celebrar o contrato. Há o ressarcimento das despesas em que a parte incorreu na expectativa de que o combinado seria cumprido. Aqui não há projeções futuras, o objetivo é apenas aliviar a parte dos danos emergentes, transportando-a de volta à posição econômica em que ela estava antes de ter suas expectativas frustradas. É uma indenização por frustração de expectativa, que leva em conta as despesas incorridas pelo autor na tentativa de cumprir sua parte do contrato. ${ }^{52}$

Esta é a solução para o credor que não conseguir comprovar os lucros cessantes, ou quando estes forem de difícil quantificação. Sobre este ponto, temos o precedente Anglia Television Ltd v. Reed ${ }^{53}$, onde um ator (réu) não participou das filmagens, mas a empresa (autora) não conseguiu demonstrar que o filme planejado seria lucrativo. A Court of Appeal, então, determinou o ressarcimento das despesas que já haviam sido realizadas antes do projeto ser descartado, e a condenação incluiu também as despesas pré-contratuais realizadas em razão das gravações. Salienta-se, no entanto, que o valor da indenização não pode abarcar nem a expectancy nem reliance caso isso proporcione ao autor um duplo ressarcimento pela mesma perda. ${ }^{54}$

No caso $C \& P v$. Middleton, surgiu uma exceção que pode ser alegada pelo réu para se livrar do dever de ressarcir o autor em reliance. Para isso ele deve demonstrar que o autor não teria capacidade de arcar com suas despesas ainda que o inadimplemento não houvesse ocorrido. Ou seja, o contrato, por si só, já causaria danos à parte inocente. A base dessa restrição ao reliance é uma questão de nexo causal, já que o contrato causaria o empobrecimento do autor mesmo que tivesse sido cumprido de forma perfeita.

\footnotetext{
${ }^{52}$ Ibid., p. 285.

${ }^{53}$ [1972] 1 QB 60, CA.

54 ANDREWS, Neil, loc. cit., p.285.
} 
Isso leva à conclusão de que os prejuízos não seriam fruto do descumprimento, o que quebra o liame necessário para caracterizar o direito de indenização. ${ }^{55}$ Nesse caso, exigir pagamento de indenização configuraria forma de punição, o que não é admitido na Common Law.

No Direito Brasileiro, temos os danos emergentes e a teoria da diferença como correspondentes similares à reliance. Os danos emergentes, igual ocorre no Direito Inglês, espelham o prejuízo concreto, aqueles gastos feitos pelo credor na convicção de que haveria o adimplemento, pois tais despesas podem ser inutilizadas no caso de inadimplemento parcial ou total. O credor poderá requerer indenização que englobe todos os gastos que, de boa-fé, suportou na tentativa de bem cumprir suas obrigações contratuais. ${ }^{56}$

Para aferir as proporções do dano patrimonial, utiliza-se a teoria da diferença, cujo fỉm é oferecer à parte lesada reparação na exata medida do dano sofrido. ${ }^{57}$ Castro Neves explica de forma clara como a teoria é aplicada:

"Fala-se em diferença, porque o autor do dano deve ser condenado a entregar ao lesado a diferença entre a situação do patrimônio do prejudicado, com o inadimplemento sofrido, e a situação (ideal) que teria caso o prejudicado não tivesse sofrido o dano. A reparação, idealmente, deve representar essa justa "diferença", de sorte que o lesado receba um valor que o coloque na exata posição econômica que teria se o dano jamais tivesse ocorrido, não o fazendo mais pobre ou mais rico." ${ }^{58}$

Temos, então, que nesse ponto, os dois sistemas jurídicos em análise são bem semelhantes.

\subsection{RESTITUTION E COMPENSATIO LUCRI CUM DAMNO}

\footnotetext{
${ }^{55}$ Ibid., p. 286.

${ }^{56}$ CASTRO NEVES, José Roberto de, loc. cit., p.338.

${ }^{57}$ BODIN DE MORAES, Maria Celina, Danos à Pessoa Humana, p. 143

${ }^{58}$ CASTRO NEVES, José Roberto de, loc. cit., p.339.
} 
Restitution (restituição) é um remedy cuja finalidade não é mensurar os danos, mas sim avaliar o que a parte culpada lucrou às custas do autor, evitando, assim, um enriquecimento sem causa. Ele não tem natureza de damages, portanto, pode ser concedido de forma cumulativa com um dos outros remédios sem que isso configure dupla indenização ou punição. Além disso, por não caracterizar damages, também pode ser concedido à parte culpada, sempre objetivando impedir o enriquecimento sem causa. Pode ser que, mesmo tendo violado o contrato, a parte culpada ainda tenha conferido algum benefício à contraparte. É uma forma de equilibrar a situação, trazendo justiça ao caso concreto.

Na verdade, como aponta Neil Andrews, a maioria dos remédios jurídicos de restituição não está vinculada a um inadimplemento, mas esta violação contratual é elemento essencial em um tipo de medida de restitution: a medida de equitable account, que será explicada mais adiante à luz do caso Attorney-General v. Blake.

No direito contratual, temos três formas relevantes de medida de restituição. O remédio pode se dar através de uma quantia de dinheiro reavida pela parte inocente em virtude da ausência total de contraprestação. Nesse caso, sendo hipótese de contrato extinto por frustration, o que ocorre quando um evento imprevisível torna o cumprimento do contrato impossível, ilegal ou altera radicalmente o propósito inicial da parte em celebrar aquele contrato, a restituição será regida pelo Law Reform (Frustrated Contracts) Act de 1943. Essa lei permite a restituição de valores ainda que não haja ausência total de contraprestação. Mas essa restituição da Lei de 1943 está sujeita ao acordo das partes. Fora esta exceção legal, a restitution também se aplica a vários outros contextos, não só na extinção contratual por frustração. O remedy também pode ser referente a produtos ou serviços já entregues, ou, ainda, uma restituição de ganhos auferidos mediante violação con- 
tratual, que foi a hipótese analisada em Attorney-General v. Blake em $2001 .^{59}$

No precedente ${ }^{60}$, a House of Lords introduziu no Direito Inglês o remédio de account of profits, que pode ser outorgado contra uma parte violadora com a finalidade de desprovê-la de lucros auferidos à custa da outra parte, para a simples violação contratual, independente de comprovação de quebra de dever de lealdade ou violação de direito patrimonial. Este, no entanto, é um remédio excepcional, que apenas será concedido mediante preenchimento de quatro requisitos, segundo Lord Nicholls: "primeiro, o autor deve poder demonstrar seu interesse legítimo; segundo, todos os demais remédios jurídicos devem ser inadequados ao caso; terceiro, o juiz deve, conforme entendimento próprio, reconhecer que o remédio em questão configura a resposta adequada à violação; e quarto, o ganho auferido deve ser atribuível a essa violação". 61

Então, evidente que o account of profits é espécie de restitution de caráter subsidiário, sendo utilizado apenas quando nenhum dos outros remédios caracterizar solução adequada. Esta adequação deverá ser analisada no caso concreto. O juiz deverá considerar as nuances do caso em julgamento, levando em conta o objeto do contrato, a finalidade da cláusula violada, as circunstâncias e consequências da violação e as circunstâncias em que a medida de reparação está sendo pleiteada. Lord Nicholls sugeriu uma diretriz útil, mas não exaustiva, que é procurar saber "se o autor tinha interesse legítimo em impedir a atividade lucrativa do réu e, assim, poupá-lo de seu lucro". ${ }^{62}$

\footnotetext{
${ }^{59}$ ANDREWS, Neil, loc. cit., p. 304.

${ }^{60}$ [2001] 1 AC 268, HL.

${ }^{61}$ ANDREWS, Neil, op. cit., p. 306.

${ }^{62}$ Ibid., p. 306.
} 
No sistema jurídico pátrio, temos o instituto do compensatio lucri cum damno, que, apesar de não ser equivalente ao remédio de restitution, é o que mais se aproxima para fins de comparação. Este é um instituto de aferição de indenização que visa verificar se o credor lesado recebeu alguma vantagem com o inadimplemento. Castro Neves traz o exemplo do locatário que se obriga contratualmente a não fazer qualquer obra no imóvel alugado. Contudo, o locatário efetua uma série de benfeitorias, que elevam o valor do imóvel, gerando vantagens ao credor lesado. Assim, de acordo com as circunstâncias do caso, a parte culpada pode compensar o dano da violação contratual com o benefício gerado por esse inadimplemento. ${ }^{63}$

\footnotetext{
${ }^{63}$ CASTRO NEVES, José Roberto de, loc. cit., p. 339.
} 


\section{CAPÍTULO III - REMÉDIOS CONVENCIONAIS: CLÁUSULAS CONTRATUAIS SOBRE O DEVER DE REPARAR OS DA- NOS}

No Direito Contratual, vigora o princípio da autonomia da vontade das partes. Assim, principalmente em contratos empresariais, em que há, em regra, uma paridade entre as partes contratantes, é possível que elas convencionem acerca do dever de reparar os danos provenientes do contrato. Podem ser ajustados critérios e limites ao dever de indenizar.

Salienta-se que só existe esta autonomia no caso da indenização ser um direito disponível, o que impossibilita a inserção dessas cláusulas em contratos de trabalho ou contratos envolvendo a administração pública, por exemplo. Sendo disponível o direito, pode ser acordado ajuste acerca da alteração de riscos quanto ao dever de indenizar, a limitação do seu valor ou, até mesmo, a supressão do ressarcimento. ${ }^{64}$

Como aponta Castro Neves:

"O ajuste quanto à reparação pode ocorrer depois de verificado o inadimplemento, ou antes mesmo de se confirmar o prejuízo causado pela falha contratual, quando as partes sequer sabem se haverá necessidade de indenização. Nestes casos, as partes de um contrato convencionam alterar a regra jurídica que seria aplicada acerca da distribuição dos riscos pelo inadimplemento, para adotar outra, que elas deliberaram."

Neste capítulo, serão analisadas, à luz dos direitos inglês e brasileiro, três espécies dessas cláusulas: a cláusula anglo-saxônica de liquidated damages, a cláusula penal e a cláusula de exclusão do dever de reparar.

\subsection{LIQUIDATED DAMAGES E CLÁUSULA PENAL}

\footnotetext{
${ }^{64}$ Ibid., p. 367.
} 


\subsubsection{LIQUIDATED DAMAGES}

A cláusula de liquidated damages (danos liquidados) da Common Law tem a finalidade de estabelecer previamente no contrato o valor da indenização por danos que o contrato possa gerar futuramente e fixar um limite máximo para o pagamento de damages.

O valor estabelecido não pode ser aleatório, devendo guardar relação direta com os danos efetivamente sofridos, compensando a parte pela perda, de acordo com parâmetros de razoabilidade. Desta forma, para que a cláusula seja válida, é preciso que o dano seja complexo e de difícil apuração, e o valor estimado deve ser fruto de estimativa realizada em conjunto pelas partes, não unilateralmente imposto.

Ainda assim, a cláusula não será exequível judicialmente se possuir caráter punitivo. Como determinado no leading case Dunlop Pneumatic Tyre Co Ltd v. New Garage \& Motor Co Ltd em $1915^{65}$, para que uma cláusula de liquidated damages seja válida, o valor a ser pago no descumprimento contratual deve caracterizar uma pré-estimativa genuína da perda que a parte inocente sofreria em razão do inadimplemento. Se a intenção da cláusula, por outro lado, for a de coagir a parte culpada a cumprir o contrato e não de compensar a parte inocente, é bem provável que ela seja vista como uma penalidade e, consequentemente, inválida.

No sistema brasileiro, também existe o conceito de danos contratualmente acordados, mas com uma lógica bem distinta da britânica, por isso deve-se ter bastante cautela ao tratar do tema, evitando-se, assim, injustiças e surpresas desagradáveis.

\footnotetext{
${ }^{65}$ [1915] UKHL 1.
} 
Em nosso direito, esta cláusula assume natureza de multa, sendo tratada doutrinariamente como cláusula penal e não uma cláusula indenizatória. Ou seja, basta a ocorrência do descumprimento contratual para que o montante devido a título de danos liquidados passe a ser integralmente devido, de acordo com o art. 408 do Código Civil. ${ }^{66}$

Além disso, como o instituto é entendido pela doutrina e jurisprudência como uma multa convencional, para se tornar exigível não é necessário que o credor demonstre ter sofrido prejuízo, sendo suficiente a comprovação de que houve o descumprimento previsto na cláusula, dando ensejo à aplicação da penalidade, nos termos do art. 416 do CC. ${ }^{67}$

\subsubsection{A CLÁUSULA PENAL}

Como mencionado acima, no Brasil, diferentemente do sistema legal britânico, os danos liquidados são tidos pela doutrina e jurisprudência como verdadeira cláusula penal.

A cláusula penal, como os liquidated damages, tem também a finalidade de estipular previamente o valor de perdas e danos devido em caso de inadimplemento, mas vai além, servindo como forma de coagir a parte a cumprir suas obrigações, em razão do papel de pena civil que a cláusula assume, incidindo independentemente da comprovação de qualquer prejuízo pelo credor, como pode ser extraído do artigo 416 do Código Civil. A incidência da penalidade depende apenas do inadimplemento. Antes disso, a exigibilidade da cláusula é potencial.

\footnotetext{
${ }^{66}$ L.O. Baptista, Schmidt, Valois, Miranda, Ferreira, Agel, Danos Acordados no Direito Comparado, ano 6, $\mathrm{n}^{\circ} 66$, outubro de 2010.

Art. 408- Incorre de pleno direito o devedor na cláusula penal, desde que, culposamente, deixe de cumprir a obrigação ou se constitua em mora.

${ }^{67}$ Ibid.

Art. 416- Para exigir a pena convencional, não é necessário que o credor alegue prejuízo.
} 
A cláusula pode ser estipulada no mesmo instrumento da obrigação principal, como uma de suas cláusulas, ou ser avençada em instrumento à parte. $\mathrm{O}$ essencial é que seja fixada anteriormente ao inadimplemento e, se em apartado, possa inequivocamente ser identificada como acessória à obrigação principal, pois a cláusula penal isolada é inexistente. ${ }^{68}$ Em razão de seu caráter acessório, ela seguirá, em regra, o destino da obrigação principal. Nula ou extinta a obrigação principal, mesmo destino recairá sobre a cláusula penal.

Este tipo de convenção contratual é comumente utilizada no Brasil, visto que, além de ser um estímulo ao cumprimento contratual, como ela já liquida de antemão o valor da indenização, isso simplifica a apuração dos prejuízos, tornando o ressarcimento pelo inadimplemento muito mais célere. ${ }^{69}$ Qualquer espécie de obrigação pode ser reforçada através de uma cláusula penal, desde que a convenção seja expressa e explícita. A aceitação da cláusula em nosso sistema pode ser vista no acórdão abaixo:

"Cláusula penal. Pré-fixação da indenização. Desnecessidade de prova pericial para apuração de qualquer valor. Julgamento antecipado da lide. Cabimento. Havendo previsão no contrato de cláusula penal, que, pela sua natureza, é ao mesmo tempo liquidação antecipada das perdas e danos e punição pelo descumprimento da avença, descabe a realização de perícia para apurar o montante da indenização. Inexistência de alegação de eventual desproporção entre o valor fixado e o real prejuízo. Não há cerceamento de defesa e nem nulidade da sentença se a prova pericial é desnecessária para a solução da lide, impondo-se o julgamento antecipado diante da causa madura, para atender os princípios da prestação jurisdicional. Des-

\footnotetext{
${ }^{68}$ SILVA PEREIRA, Caio Mário da, loc. cit., p. 141.

${ }^{69}$ CASTRO NEVES, José Roberto de, loc. cit., p. 380.
} 
provimento do recurso" (TJRJ, Apelação Cível n 25.769/2003, Relator Desembargador Sérgio Cavalieri Filho). ${ }^{70}$

Apesar de seu caráter de multa civil, qualificar a cláusula penal meramente como punição é demasiadamente simplista e pode não condizer com a realidade. O que as partes convencionam é uma antecipação do valor da indenização para o caso do descumprimento contratual. Pode ser que o dano sofrido pela parte lesada seja menor do que o ajustado na cláusula e, neste cenário, de fato teremos uma punição, já que a parte culpada terá que arcar com uma indenização superior à que seria devida para reparar o prejuízo efetivamente sofrido. Mas o contrário também é possível: o dano provindo do inadimplemento pode ser superior ao montante estipulado na cláusula e, neste caso, a convenção contratual servirá como limitação de responsabilidade. Conclui-se que a natureza da cláusula penal pode depender do resultado da operação. ${ }^{71}$

Existem dois tipos de cláusula penal acolhidas pelo direito pátrio: a compensatória, que se aplica ao inadimplemento total, e a moratória, incidente no caso de mora ou descumprimento de alguma estipulação contratual isolada.

A espécie compensatória confere ao credor, diante do inadimplemento, optar entre o pagamento da indenização prevista na cláusula, ou a prestação em espécie, como se extrai do artigo 410 do Código. Esta opção cabe apenas ao credor, é claro. Para o devedor, a obrigação é uma só: cumprir o que se obrigou. É ao credor que cabe escolher entre o cumprimento da obrigação e a multa convencionada. Este tipo de cláusula penal tem caráter substitutivo, objetivando suprir ao credor o que o inadimplemento the

\footnotetext{
${ }^{70}$ Apud. Ibid..

${ }^{71}$ Ibid., p.381.
} 
retirou, como ensina Caio Mário. ${ }^{72}$ Isso é um claro reflexo da preferência concedida por nosso ordenamento jurídico à execução específica das obrigações, em oposição ao sistema inglês, que dá destaque às perdas e danos.

Na cláusula penal moratória, por sua vez, o credor pode exigir cumulativamente o valor convencionado e o cumprimento da obrigação principal, de acordo com os artigos 409 e 410, CC. Caso a prestação principal já não seja mais possível ou do interesse do credor, ele pode exigir a penal moratória mais as perdas e danos, desde que nestas o valor da multa já não se encontre embutido, configurando bis in idem. Esta cláusula pode se referir à hipótese de execução imperfeita ou não satisfatória da obrigação, que tanto diz respeito ao tempo, como ainda ao modo de realizar a prestação, que diverge da forma especificada pelas partes no contrato. ${ }^{73}$

O artigo 416 do Código Civil de 2002 expressamente vedou a possibilidade de indenização suplementar em favor do $\operatorname{credor}^{74}$, mas isso não é norma de ordem pública, podendo haver a majoração da indenização na presença de expressa disposição contratual que contemple esta possibilidade. Neste caso, o montante previsto na cláusula servirá meramente como um valor mínimo, podendo ser estendido até o limite do real prejuízo sofrido pela parte inocente.

No artigo 412 do Código, há previsão de um limite máximo para a fixação do montante na cláusula penal compensatória, que é o valor total da obrigação principal. Esta, diferentemente da norma do artigo 416, é norma de ordem pública, não podendo ser afastada pela vontade das partes. O que tiver sido estipulado a mais é desconsiderado. Mas cumpre entender o "valor da obrigação principal" como abrangendo todos os custos com o cum-

\footnotetext{
${ }^{72}$ SILVA PEREIRA, Caio Mário da, loc. cit., p. 147.

${ }^{73}$ FULGÊNCIO, Tito. Apud. Ibid., p. 146.

${ }^{74}$ SILVA PEREIRA, Caio Mário da, loc. cit., p. 147.
} 
primento da obrigação, de forma que o eventual inadimplemento possa ser reparado de forma efetiva. ${ }^{75}$

A cláusula penal moratória não encontra limites no artigo 412, mas pode ter seu valor restringido por outras normas, como, por exemplo, o Código do Consumidor.

Quanto à redução do valor fixado na cláusula penal, o artigo 413 do Código Civil estabelece que o magistrado deve reduzir equitativamente a penalidade se a obrigação principal tiver sido cumprida em parte e o montante for excessivo ${ }^{76}$, pois a pena não pode gerar efeitos iníquos à outra parte, devendo estar em consonância com os princípios da função social do contrato, o equilíbrio das prestações e a boa-fé objetiva. ${ }^{77} \mathrm{O}$ juiz pode realizar esta redução ex officio, não tendo permissão, no entanto, para suprimir integralmente a cláusula.

O sistema da Common Law não reconhece a validade das cláusulas penais $^{78}$, com fundamento no princípio da penalização, estabelecido em Dunlop v. New Garage (1915) ${ }^{79}$. Neste caso, Lord Dunedin disse que "a essência de uma penalidade é um pagamento em dinheiro, determinado como forma de coibir a parte violadora". Então, é evidente que o conceito brasileiro de cláusula penal como multa civil não seria válido perante um tribunal inglês.

É possível, no entanto, que a cláusula prospere se ficar demonstrado que sua essência é o legítimo acordo sobre prefixação de danos, pois, neste caso, ela valerá como uma cláusula de liquidated damages, aceita em

\footnotetext{
${ }^{75}$ CASTRO NEVES, José Roberto de, loc. cit., p. 382.

${ }^{76}$ Ibid., p. 383.

${ }^{77}$ SILVA PEREIRA, Caio Mário da, loc. cit., p. 141.

${ }^{78}$ Importante diferenciar a cláusula penal dos punitive damages, que são punições aplicadas pelos tribunais e não convencionadas pelas partes no contrato.

${ }^{79}$ [1915] AC 70, 86-8, HL.
} 
Common Law. Como explicou Lord Dunedin, saber se o valor determinado é penalidade ou liquidated damages é uma questão de interpretação a ser realizada com base nos termos e circunstâncias inerentes de cada contrato específico, julgados ao tempo da formação do contrato, e não no momento da violação. ${ }^{80}$

Então, caberá aos tribunais decidir se a cláusula tem natureza de $l i$ quidated damages, sendo válida, ou de penalidade, devendo ser suprimida. Para realizar esta tarefa interpretativa, ao longo do tempo a jurisprudência foi criando testes para descobrir a natureza da cláusula em análise. No caso Dunlop, foi levantado o antigo corolário que diz que será vista como penalidade "se a violação consistir somente na falta de pagamento de montante em dinheiro, e o valor prefixado for maior do que o montante que deveria ser pago". Lord Dunedin também estabeleceu que há presunção de que se trata de uma punição quando o contrato estipula "pagamento de uma prestação única, a título de ressarcimento, em razão da ocorrência de algum dos ou de todos os eventos previstos, alguns capazes de causar sérios danos e outros nada mais do que danos irrisórios. ${ }^{81}$ A partir deste teste, cairia por terra a cláusula penal brasileira, cuja incidência ocorre independentemente de qualquer prejuízo efetivo ao credor, bastando o simples inadimplemento contratual. No Direito Inglês, se a parte culpada conseguir demonstrar que o descumprimento não gerou dano, a cláusula será anulada.

Em Alfred McAlpine Capital Projects Ltd v. Tilebox $L t d^{82}$ foi sugerido que se estaria diante de uma penalidade se houvesse "discrepância substancial entre o valor do dano estipulado no contrato e o valor do dano possível de acontecer". Este seria um teste objetivo, independente da boa-fé das partes ao estipularem o montante. Neste ponto, há alguma semelhança com

\footnotetext{
${ }^{80}$ Ibid.

${ }^{81}$ Ibid.

${ }^{82}$ [2005] EWHC (TCC) 281; [2005] BLR 271, 280, [48], por J. Jackson.
} 
o sistema pátrio no que tange a possibilidade do juiz brasileiro reduzir equitativamente o valor da cláusula quando o montante for excessivo.

Então, para que uma cláusula penal seja tida como danos liquidados, podendo sobreviver, deve-se estar diante de um contexto contratual em que é muito difícil estimar com precisão as perdas que o inadimplemento pode ocasionar, e o objetivo da convenção deve ser apenas uma previsão do valor indenizatório, não podendo configurar coerção para o cumprimento da obrigação. Além disso, o montante prefixado deve seguir padrão de razoabilidade.

A vedação às cláusulas penais em Common Law é alvo de muitas críticas e vem sendo mitigada nas transações comerciais, em que há uma paridade entre as partes contratantes. No caso Jeancharm Ltd v. Barnet Football Club $\operatorname{Ltd}^{83}$, Lord Jacob disse que o Judiciário, apesar de ainda aplicar o precedente Dunlop, tem entendido que a análise da cláusula como penalidade deve ser feita com cautela quando as partes envolvidas tiverem o mesmo poder de negociação. E, em Philips Hong Kong Ltd v. AttorneyGeneral for Hong Kong (1993) ${ }^{84}$ foi recomendado que o juiz seja cauteloso, evitando a criação de "um padrão muito limitado" e levando em conta que a regra da autonomia da vontade das partes prega que o que foi acordado no contrato deve ser mantido. Lord Woolf destacou, no caso, que "qualquer outra abordagem resultará em uma incerteza indesejada, especialmente em contratos comerciais". Mas mesmo nessas situações, a cláusula poderá ser invalidada se envolver valor exagerado e desarrazoado.

Pode-se concluir que no Direito Brasileiro, a regra é a cláusula penal, tendo em vista que os liquidated damages são entendidos pela doutrina e jurisprudência como uma multa civil. E no Direito Inglês temos apenas a

\footnotetext{
${ }^{83}$ [2003] EWCA Civ. 58; 92 Con LR 26.

${ }^{84}$ [1993] 61 BLR 41, 54-5, 59, PC.
} 
possibilidade de liquidated damages, em princípio, devido aos maus olhos com que são vistas as sanções privadas estabelecidas contratualmente.

\subsection{CLÁUSULAS DE EXCLUSÃO DO DEVER DE REPARAR}

A cláusula de exclusão do dever de reparar pode ser de quatro tipos: a que limita o valor máximo da indenização, a que exclui uma situação específica do dever de indenizar, a que limita no tempo a possibilidade de reclamar o ressarcimento, funcionando como uma prescrição antecipada e, por último, a mais potente de todas, que é a cláusula de não indenizar, que exclui por completo a obrigação de compensar os prejuízos sofridos pela parte frustrada (considerado dever secundário no direito pátrio e primário em Common Law).

Apesar de possuírem efeitos práticos iguais, no direito nacional é importante diferenciar a cláusula de não indenizar da cláusula de irresponsabilidade. Segundo Caio Mário, enquanto a cláusula de irresponsabilidade exclui o dever jurídico de responder pelo dano, a cláusula de não indenizar afasta a obrigação de reparar os prejuízos impostos à vítima. ${ }^{85}$ Para boa parte da doutrina brasileira, a exclusão contratual da responsabilidade seria nula, visto que o afastamento só poderia se dar por força de lei, como no caso da legítima defesa, por exemplo. A Common Law também faz esta distinção na Seção 3 do Unfair Contract Term Act, mas permite a discricionariedade dos tribunais ao analisarem a razoabilidade da cláusula de exclusão de responsabilidade para fins de validação. Então, a cláusula, ainda que restritiva da responsabilidade em si, ainda poderá sobreviver, se julgada razoável, como será explicado mais adiante.

\footnotetext{
${ }^{85}$ SILVA PEREIRA, Caio Mário da, loc. cit., p. 325.
} 
A cláusula de não indenizar é permitida, em regra, no Direito Brasileiro, em contratos paritários (em que ambas as partes participam da negociação das cláusulas) desde que ausentes limitações de ordem pública, como, por exemplo, o artigo 25 do Código do Consumidor, que veda a limitação nas relações de consumo. Também é necessário para sua validade, a verificação de alguma forma de contraprestação à parte que tem seu direito à indenização suprimido. Ela deve auferir alguma sorte de vantagem para aceitar essa restrição à sua possibilidade de ressarcimento por eventuais prejuízos.

No caso do consumidor, a vedação do artigo 25 é para a hipótese do consumidor pessoa física. Já para o consumidor pessoa jurídica, o artigo 51 do CDC admite, desde que justificável, a limitação de responsabilidade do fornecedor, mas não a total exoneração, cabendo ao juiz analisar no caso concreto a validade da cláusula. ${ }^{86}$ Neste ponto, percebe-se algo em comum com os testes de razoabilidade aplicados pelos tribunais britânicos, havendo também um pouco mais de discricionariedade para que o juiz brasileiro verifique, nos elementos do caso sob julgamento, a justificativa para a limitação de responsabilidade.

Sergio Cavalieri Filho também salienta que, mesmo em conformidade com a ordem pública, a cláusula não será admitida se no inadimplemento concorrer dolo ou culpa grave do devedor, pois, caso contrário, estaria-se concedendo um passe livre à má-fé. ${ }^{87}$ Entendimento semelhante será visto mais a frente quando falarmos sobre as normas inglesas repressoras da prática de fraude.

Ademais, a jurisprudência ensina que a cláusula não poderá ser afixada em relação à responsabilidade por elementos substanciais do contrato:

\footnotetext{
${ }^{86}$ NADER, Paulo, Curso de Direito Civil, volume 7, Responsabilidade Civil, p.141.

${ }^{87}$ CAVALIERI FILHO, Sergio, Programa de Responsabilidade Civil, p. 392.
} 
"Responsabilidade civil. Banco. Cofre de aluguel violado. Furto de jóias. Cláusulas de não-indenizar. Prevalência da obrigação de guarda e segurança. Prova do dano.

O banco é civilmente responsável, no caso de subtração de valores, guardados em cofres-fortes, alugados a seus clientes. A cessão do uso do compartimento envolve uma particular prestação de proteção e segurança. Responsabilidade presumida elidível em caso fortuito ou força maior. Inválida a cláusula de não indenizar, porque excludente de obrigação essencial do contrato, qual seja, a de guardar o local dos cofres e implicitamente seu conteúdo" (TJRJ, $2^{\circ}$ Grupo de Câmaras Cíveis, EI 31/90 na Ac. 2.860, Relator Desembargador Paulo Roberto A. Freitas, julgado em 3.9.1991). ${ }^{88}$

Na mesma linha de entendimento do TJRJ, o STF vetou a cláusula de não indenizar nos contratos de transporte com a edição da súmula 161, visto que o transportador não pode se eximir da obrigação que constitui essência do contrato.

Quando a cláusula estabelece indenização irrisória, ela será compreendida como exclusão do dever de indenizar, aplicado-se as mesmas limitações acima mencionadas.

No Direito Inglês a questão das cláusulas de exclusão é trabalhada, em primeira análise, de acordo com três regras básicas: incorporação, interpretação e impossibilidade de exclusão da responsabilidade por fraude ou declaração falsa.

\footnotetext{
${ }^{88}$ Apud. CASTRO NEVES, José Roberto de, loc. cit., p. 371.
} 
Primeiro, é verificado se houve a incorporação da cláusula no contrato, ou seja, a limitação faz parte do documento contratual (ou documento apartado com status contratual). Isso pode ocorrer das seguintes maneiras: assinatura da cláusula pelas partes no contrato, independentemente da comprovação de que a parte efetivamente leu ou compreendeu os efeitos da cláusula $^{89}$; não havendo a assinatura, o proferens (parte que quer se valer da cláusula a seu favor) deve demonstrar que tomou as medidas razoáveis necessárias para que uma pessoa razoável tivesse ciência da cláusula, então, novamente, não é necessário que a outra parte tenha de fato lido e entendido a cláusula, bastando este teste de razoabilidade, de acordo com Parker $v$ SE Railway Co $(1877)^{90}$. A cláusula não terá validade se estabelecida após a formação do contrato $^{91}$, ou quando afixada em documento que não aparenta ter qualquer força contratual, como determinado em Chapelton v. Barry $U D C(1940)^{92}$.

Neil Andrews destaca que a incorporação pode ocorrer, também, em razão do curso de negociações realizadas pelas partes ou das práticas comerciais. $^{93}$

Ultrapassado este primeiro teste sobre a incorporação da cláusula, vem a questão da interpretação, que, assim como no sistema brasileiro, deve ser feita em desfavor da parte que quer impor a incidência da cláusula de exclusão. $\mathrm{O}$ direito inglês exige que a linguagem utilizada para excluir a responsabilidade por negligência no contrato seja clara, sem ambiguidades, por ser incomum que alguém deseje celebrar um contrato em que, mesmo em caso de culpa do devedor, não haverá direito a reparação. O precedente

\footnotetext{
${ }^{89}$ L'Estrange v F Graucob Ltd [1934] 2 KB 394 Div. Ct.

90 [1877] 2 CPD 416, CA.

${ }^{91}$ Thornton v. Shoe Lane Parking [1971] 2 QB 163, CA.

${ }^{92}$ [1940] 1 KB 532, CA. Apud. ANDREWS, Neil, loc. cit., p.210.

${ }^{93}$ ANDREWS, Neil, op. cit., p.210.
} 
Canada SS Lines Ltd v. The King (1952) ${ }^{94}$ estabeleceu, então, princípios alternativos de interpretação para esclarecer se as partes legitimamente escolheram excluir a indenização em caso de negligência:

(i) a palavra "negligência" deve estar expressa na cláusula;

(ii) se o termo não for expresso no contrato, haverá a exclusão do dever de reparar apenas se a redação da cláusula for clara o suficiente para levar a esse entendimento, caso contrário, a interpretação será em desfavor do proferens (interpretação contra proferentem).

Outra forma de controle da cláusula de exclusão é a regra que invalida as tentativas de excluir ou restringir a responsabilidade por fraude ${ }^{95}$, que, semelhantemente às normas brasileiras, visa impedir a impunidade das condutas de má-fé.

Além dessas regras jurisprudenciais, existem ainda as contidas em dois Statutes, que são leis no sentido romano-germânico da palavra. Tem-se o Unfair Contract Term Act de 1977 (UCTA) e o Unfair Terms in Consumer Contracts Regulations de 1999 (os "Regulamentos"), que convivem num dualismo complexo e caótico, sendo, por vezes, difícil identificar qual a lei aplicável.

O UCTA se aplica a questões comerciais e consumeristas exclusivamente no que tange a exclusão e restrição de responsabilidade por inadimplemento ou violação do dever de cuidado (conhecido em Common Law como tort).

Os Regulamentos, mais restritos, tratam apenas das relações de consumo em que o consumidor é pessoa física, regendo os termos contratuais

\footnotetext{
94 [1952] AC 192, 208, PC.

95 ANDREWS, Neil, loc. cit., p.210.
} 
que não foram negociados individualmente pelas partes (como ocorre em contratos de adesão), com o fim de evitar o desequilíbrio na relação. Por esta lei, qualquer termo contrário à boa-fé será nulo.

Pela seção 2 do UCTA, não é permitido excluir a responsabilidade por morte ou lesão corporal resultante de negligência (violação do duty of care), mas a indenização por outros tipos de danos, como os patrimoniais, desde que dentro das balizas da razoabilidade, pode ser afastada, como visto nos princípios de Canada SS Lines Ltd v. The King. Aqui, uma clara semelhança com as normas brasileiras, que, mesmo em contratos paritários, consideram nula a cláusula de não indenizar nos casos de prática de esportes de risco, sob o fundamento da dignidade da pessoa humana, que é inafastável.

A Seção 3 do UCTA traz restrições à estipulação da cláusula de exclusão quando uma das partes é consumidor pessoa física, ou na presença de termos escritos padrão não negociáveis impostos à outra parte, sendo ela consumidora ou não ${ }^{96}$. Neste ponto, a lei proíbe que a cláusula seja utilizada para excluir a possibilidade de responsabilização pelo inadimplemento, o que condiz com a diferenciação que os doutrinadores brasileiros fazem entre a exclusão de responsabilidade e do dever de reparar. Também fica vedada a convenção cujo fim seja permitir que o cumprimento contratual se dê de forma substancialmente diversa daquela esperada pelo credor, o que parece semelhante à regra do art. 313 do Código Civil, segundo o qual, “o credor não é obrigado a receber prestação diversa da que lhe é devida, ainda que mais valiosa".

Ainda que a cláusula de exclusão se encaixe em alguma destas hipóteses, ela ainda poderá sobreviver se passar no teste de razoabilidade feito

\footnotetext{
${ }^{96}$ St Alban`s City \& DC v International Computers Ltd [1996] 4 A11 ER 481, 491, CA.
} 
pelo juiz, que levará em consideração uma série de questões de acordo com o caso concreto.

O UCTA também se aplica no caso dos termos implícitos inseridos pela lei (Sale of Goods Act de 1979 e Supply of Goods (Implied Terms) Act de 1973) nos contratos para venda de bens, estando ou não o fornecedor atuando no curso de atividade comercial. Quando o vendedor for o proprietário dos bens vendidos, independentemente do comprador ser um consumidor ou o fornecedor estar agindo em atividade comercial, a responsabilidade pela violação de algum dos termos implícitos pelas leis não poderá ser excluída ou restringida ${ }^{97}$. Os termos impostos pelos statutes mencionados dizem respeito às declarações e garantias, qualidade do bem (na venda por amostragem o bem fornecido deve estar em conformidade com a amostra, adequado ao seu propósito e aos padrões de qualidade) e ressarcimento.

Em relação aos termos implícitos, o UCTA adota um sistema de controle de dois níveis, dependendo da parte inocente ser ou não um consumidor. A responsabilidade pelo descumprimento dos termos implícitos não poderá ser excluída em desfavor do consumidor, mas é possível a exclusão ou restrição quando a parte não for caracterizada como consumidor (caso ela exerça a atividade comercialmente, como em L`Estrange v F Graucob $L t d$, por exemplo), desde que a cláusula passe no teste de razoabilidade. Provavelmente, a cláusula será razoável se o comprador teve a chance de inspecionar os bens. ${ }^{98}$

Assim como no Direito Brasileiro (art.25, CDC), o UCTA veda a exclusão das perdas e danos derivadas de negligência do produtor ou distribuidor nas relações de consumo, em que se constata uma disparidade de forças entre as partes.

\footnotetext{
${ }^{97}$ ANDREWS, Neil, loc.cit., p.213.

${ }^{98}$ Ashurst LLP, Limitation and Exclusion of Liability, 2009. (tradução minha)
} 
Várias disposições do UCTA exigem que os tribunais apliquem um teste de razoabilidade para determinar a validade de uma dada cláusula. $\mathrm{O}$ ônus probatório recai sobre a parte que busca aproveitar a cláusula em seu favor, como no sistema brasileiro. ${ }^{99}$ Mas em se tratando de cláusula estipulada entre empresários, em situação de equilíbrio de forças, Watford Electronics Ltd v. Sanderson CFL Ltd (2001) ${ }^{100}$ recomendou que os tribunais deveriam ser cautelosos ao invalidar uma cláusula de exclusão por ser desarrazoada, a nao ser que uma das partes tenha, efetivamente, "obtido uma vantagem injusta em face da parte adversa ou a corte esteja convencida que um termo é tão desarrazoado que ele não pode ser compreendido ou consi-

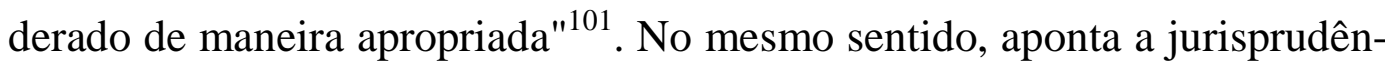
cia pátria, que, na ausência de limitações de ordem pública, vem reconhecendo a validade da cláusula de exclusão do dever de reparar nas relações entre partes capazes, ainda mais quando praticantes da atividade empresária:

"Comercial. Direito Marítimo. Transporte. Cláusula limitativa de responsabilidade. Validade. Precedente da Segunda Seção. Recurso desacolhido.

É válida a cláusula limitativa da responsabilidade de indenizar inserida em contrato de transporte marítimo" (RESP no 36.706/SP - $4^{\mathrm{a}}$ Turma - STJ - Relator Ministro Sálvio de Figueiredo Teixeira, julgado em 05.11.1996). ${ }^{102}$

A seção 11(2) e o Anexo 2 do UCTA indicam 5 guidelines exemplificativas que podem ser utilizadas no teste de razoabilidade de uma cláusula de exclusão:

\footnotetext{
${ }^{99}$ ANDREWS, Neil, op.cit., p. 214.

${ }^{100}$ [2001] 1 A11 ER (Comm) 696.

101 ANDREWS, Neil, loc. cit., p.214.

${ }^{102}$ Apud. CASTRO NEVES, José Roberto de, loc. cit., p.372.
} 
(i) a equivalência do poder de barganha das partes;

(ii) se a parte recebeu alguma vantagem como contraprestação à aceitação da cláusula (exigência presente no Direito Brasileiro);

(iii) se o cliente sabia ou deveria ter conhecimento da inclusão da cláusula;

(iv) se os bens eram manufaturados, processados ou adaptados por solicitação especial do cliente;

(v) sendo uma cláusula que exclua a responsabilidade apenas no caso do não cumprimento de uma condição contratual, qual era a probabilidade dessa condição ser praticável ao momento da formação do contrato. ${ }^{103}$

O efeito da reprovação no teste de razoabilidade é a invalidação da cláusula. E, sendo inválida, o juiz não poderá preservar a parte "razoável", devendo excluí-la por completo. Poder diferente é concedido aos magistrados brasileiros, que, no julgamento de cláusula ampla, com diversas especificações, nem todas contrárias à ordem pública ou ferindo os princípios da boa-fé, as regulares deverão ser aproveitadas, não se justificando a nulidade absoluta. $^{104}$

Enquanto o UCTA trata exclusivamente das cláusulas de exclusão, os Regulamentos aplicam-se aos termos contratuais em geral, mas apenas quando a relação jurídica se der entre um consumidor pessoa física e um vendedor/fornecedor atuando profissionalmente em atividade comercial. Então, no âmbito dos Regulamentos há uma extensão das matérias reguladas, mas também uma restrição subjetiva.

Os Regulamentos regem as cláusulas contratuais que não houverem sido negociadas individualmente quando estas trouxerem um desequilíbrio ao negócio jurídico em prejuízo do consumidor, de forma contrária à boa-

\footnotetext{
${ }^{103}$ ANDREWS, Neil, op. cit., p.214.

${ }^{104}$ NADER, Paulo, loc. cit., p.142.
} 
fé. Nestes casos, o termo contratual será havido como injusto. Então, enquanto no UCTA vigora a regra da razoabilidade, aqui tem-se o critério da injustiça. $^{105}$

Sendo injusta, a cláusula não vinculará o consumidor e o resto do contrato poderá ser mantido, se ainda preservar seu sentido após a retirada do termo injusto.

Os Regulamentos trazem um tratamento cuidadoso para as relações de consumo, em que se lida com a hipossuficiência, assim como o faz o Direito Brasileiro. No entanto, no tocante às cláusulas de exclusão do dever de reparar afixadas ao contrato em detrimento do consumidor, o tratamento conferido pelo UCTA, que impede a exclusão do direito de indenização do consumidor, se assemelha mais à proteção conferida no Brasil.

${ }^{105}$ Ashurst LLP, loc.cit. (tradução minha). 


\section{CAPÍTULO IV - SÍNTESE COMPARATIVA}

Ao cotejarmos os sistemas jurídicos inglês e brasileiro, constatamos que a primeira diferença essencial encontrada, é que, para os brasileiros, em face ao inadimplemento, o dever primário que surge, antes de se pensar em indenizações, é a execução específica da obrigação, buscando-se preservar o cumprimento estipulado pelas partes inicialmente. Já para os ingleses, povo marcado pelo pragmatismo, entende-se que forçar a performance específica da obrigação, mantendo vinculadas as partes cuja relação já foi estremecida pelo inadimplemento não seria razoável, dando-se, portanto, preferência ao ressarcimento pecuniário, através dos damages.

Passando para o tema da forma de indenização, o sistema inglês prevê dois remedies: expectancy e reliance, que bastante se aproximam de alguns institutos previstos em nosso sistema.

Para expectancy, que é o remédio preferível para a parte frustrada, oferecendo a possibilidade de colocá-la na posição em que se encontraria caso o contrato tivesse sido devidamente cumprido, temos como correspondentes os lucros cessantes e a teoria da perda de uma chance. Os lucros cessantes, assim como o remedy mencionado, configuram uma projeção futura para compensar o credor pela "perda de um negócio". A teoria da perda de uma chance, por sua vez, busca a compensação por um dano cuja ocorrência é incerta. É o ressarcimento pela perda da possibilidade de se obter uma vantagem com base em meras probabilidades. Em relação a esta teoria, ambos sistemas jurídicos prevêem sua aplicação apenas quando a chance de se obter o proveito em questão é real, não podendo se basear simplesmente em especulações.

Quando a parte não fizer jus ao ressarcimento a título de reliance, ela ainda poderá obter indenização em expectancy, que não é tão potente, 
conseguindo apenas levar a parte de volta à posição econômica em que ela se encontrava antes do inadimplemento, compensando-a pelas despesas em que, legitimamente, incorreu na expectativa de que a obrigação seria cumprida. A este instituto, podemos comparar os danos emergentes, que correspondem ao prejuízo concreto sofrido pela parte inocente, aos gastos que ela teve para bem cumprir o combinado, que foram inutilizados pelo inadimplemento da contraparte. E a teoria da diferença é o instrumento utilizado para quantificar esses danos.

A Common Law também prevê o remédio de restitution, que não é uma forma de mensurar os damages, como os outros dois, mas sim de mensurar o que a parte culpada lucrou com a quebra do contrato. Ele não tem natureza de damages, visando, na verdade, impedir o enriquecimento sem causa. Por isso, também pode ser requerido pela parte culpada, se ela tiver, apesar do inadimplemento, conferido algum benefício ao credor. No Direito Brasileiro, o que mais se aproxima desse remédio é o compensatio lucri cum damno, que pode ser alegado pela parte culpada. Consiste na compensação entre o dano causado com o inadimplemento e o lucro que esta mesma violação pode ter gerado à parte lesada.

Além dos remédios previstos em lei para o inadimplemento, o princípio da autonomia da vontade também possibilita que as partes convencionem no contrato os efeitos da violação de uma das obrigações combinadas. É possível prefixar, excluir, limitar ou até agravar o dever de reparar.

Pela cláusula de liquidated damages do sistema inglês, é possível prefixar o montante de indenização a ser paga pelo descumprimento, mas o valor deve ser uma representação realista dos prejuízos, não podendo caracterizar uma punição. No Brasil, por outro lado, a penalização é possível e, inclusive, os liquidated damages serão interpretados como multa civil, assumindo posição de cláusula penal. 
A cláusula penal pode servir como limitadora da responsabilidade, quando for fixada em valor menor do que os danos efetivamente causados, ou como punição, quando o inadimplemento causar prejuízo em valor abaixo do fixado, ou até no caso de nenhum dano advir do descumprimento. Tal indenização na ausência de danos não seria possível no Direito Inglês, que rechaça a utilização de danos prefixados que tenham por objetivo coagir a parte a cumprir sua obrigação contratual. Conclui-se que, no Brasil, temos apenas a cláusula penal e, na Inglaterra, apenas os liquidated damages.

Outra possibilidade nas convenções sobre o dever de reparar é a cláusula de exclusão, que afasta esse dever. Esta limitação encontra respaldo nos dois sistemas, mas apenas quando não esbarrar em normas de ordem pública nem for instrumento para a impunidade das condutas de má-fé, além de outras restrições pontuais. Sendo termo contratual limitador do direito da parte, os tribunais brasileiros e britânicos a interpretam a favor da parte prejudicada e exigem, para sua validade, que a parte cujo direito à reparação foi limitado receba alguma vantagem como contraprestação. Então, neste ponto, os dois sistemas jurídicos guardam laços estreitos de semelhança. Mas, salienta-se que, para sobreviver, a cláusula deverá passar por testes de razoabilidade ao ser julgada pelo magistrado inglês.

Para melhor visualização dos pontos de aproximação e de distanciamento dos remédios em tela, e a título de síntese do acima exposto, confeccionamos o quadro comparativo que apresentamos abaixo.

\begin{tabular}{|l|l|l|}
\hline & DIREITO INGLÊS & $\begin{array}{l}\text { DIREITO } \\
\text { BRASILEIRO }\end{array}$ \\
\hline $\begin{array}{l}\text { Specific Performance } \\
\text { Damages e Perdas e }\end{array}$ & Remédio excepcional & Remédio preferencial \\
\hline - Remédio preferencial & $\begin{array}{l}\text { - indenização simbólica } \\
\text { se o evento não causar } \\
\text { danos }\end{array}$ & $\begin{array}{l}\text { - indenização só pode } \\
\text { advir de dano efetivo } \\
\text { atribuível ao devedor }\end{array}$ \\
\hline Dever de mitigar o & Origem em precedente & Segue modelo inglês e \\
\hline
\end{tabular}




\begin{tabular}{|c|c|c|}
\hline prejuízo & judicial & $\begin{array}{l}\text { encontra respaldo no } \\
\text { princípio da boa-fé. }\end{array}$ \\
\hline $\begin{array}{l}\text { Expectancy e Lucros } \\
\text { Cessantes }\end{array}$ & $\begin{array}{l}\text { - principal remédio em } \\
\text { damages } \\
\text { - perda de negócio } \\
\text { - busca colocar a parte } \\
\text { frustrada na posição em } \\
\text { que ela se encontraria } \\
\text { se fosse cumprido o o } \\
\text { contrato. } \\
\text { - previsibilidade do da- } \\
\text { no e certeza razoável }\end{array}$ & $\begin{array}{l}\text { - o que o credor razoa- } \\
\text { velmente deixou de lu- } \\
\text { crar } \\
\text { - dano deve ser razoa- } \\
\text { velmente identificado, } \\
\text { não sendo indenizada } \\
\text { mera especulação }\end{array}$ \\
\hline $\begin{array}{l}\text { Teoria da perda de } \\
\text { uma chance }\end{array}$ & $\begin{array}{l}\text { - Percentuais de proba- } \\
\text { bilidade não são a téc- } \\
\text { nica adequada para afe- } \\
\text { rir o quantum indeniza- } \\
\text { tório. } \\
\text { - Indenização é definida } \\
\text { de acordo com o caso } \\
\text { concreto, por meio de } \\
\text { estimativas do que a } \\
\text { parte ganharia com a- } \\
\text { quele negócio. }\end{array}$ & $\begin{array}{l}\text { - Indenização com base } \\
\text { em percentuais na pro- } \\
\text { babilidade de o evento } \\
\text { se concretizar na ausên- } \\
\text { cia do inadimplemento }\end{array}$ \\
\hline $\begin{array}{l}\text { Reliance e Danos } \\
\text { Emergentes }\end{array}$ & $\begin{array}{l}\text { - frustração de expecta- } \\
\text { tiva } \\
\text { - ressarcimento das } \\
\text { despesas em que a parte } \\
\text { incorreu na expectativa } \\
\text { de que o combinado se- } \\
\text { ria cumprido }\end{array}$ & $\begin{array}{l}\text { - semelhante ao sistema } \\
\text { inglês }\end{array}$ \\
\hline $\begin{array}{l}\text { Restitutio e Compen- } \\
\text { satio Lucri cum Dam- } \\
\text { no }\end{array}$ & $\begin{array}{l}\text { - objetivo de avaliar o } \\
\text { que a parte culpada lu- } \\
\text { crou com o inadimple- } \\
\text { mento, evitando enri- } \\
\text { quecimento sem causa } \\
\text { - não tem natureza de } \\
\text { damages, podendo ser } \\
\text { concedido também à } \\
\text { parte culpada }\end{array}$ & $\begin{array}{l}\text { - instituto de aferição de } \\
\text { indenização que visa } \\
\text { verificar se o credor le- } \\
\text { sado recebeu alguma } \\
\text { vantagem com o ina- } \\
\text { dimplemento } \\
\text { - possibilidade de a par- } \\
\text { te culpada compensar o } \\
\text { dano gerado pelo ina- } \\
\text { dimplemento com o lu- }\end{array}$ \\
\hline
\end{tabular}




\begin{tabular}{|c|c|c|}
\hline & & $\begin{array}{l}\text { cro proporcionado à ou- } \\
\text { tra parte }\end{array}$ \\
\hline $\begin{array}{l}\text { Liquidated Damages e } \\
\text { Cláusula Penal }\end{array}$ & $\begin{array}{l}\text { - estabelece previamen- } \\
\text { te valor da indenização, } \\
\text { fixando limite máximo } \\
\text { condizente com o dano } \\
\text { sofrido } \\
\text { - dano deve ser com- } \\
\text { plexo e de difícil esti- } \\
\text { mativa } \\
\text { - valor da cláusula esti- } \\
\text { pulado conjuntamente } \\
\text { pelas partes } \\
\text { - não pode ter caráter } \\
\text { punitivo } \\
\text { - cláusula com intuito } \\
\text { de coagir a outra parte a } \\
\text { cumprir contrato é tida } \\
\text { como punitiva e, por- } \\
\text { tanto, inexequível }\end{array}$ & $\begin{array}{l}\text { - tem sempre natureza } \\
\text { de multa, podendo as- } \\
\text { sumir caráter punitivo } \\
\text { - desnecessária com- } \\
\text { provação de dano sofri- } \\
\text { do, bastando o descum- } \\
\text { primento da obrigação } \\
\text { - finalidade de apurar } \\
\text { de antemão o valor da } \\
\text { indenização, mas tam- } \\
\text { bém de coagir a parte a } \\
\text { cumprir o contrato } \\
\text { - valor máximo não po- } \\
\text { de ultrapassar valor da } \\
\text { obrigação principal }\end{array}$ \\
\hline $\begin{array}{l}\text { Cláusula de Exclusão } \\
\text { do Dever de Reparar }\end{array}$ & $\begin{array}{l}\text { - também faz a distin- } \\
\text { ção, mas a cláusula de } \\
\text { irresponsabilidade pode } \\
\text { ser válida se passar por } \\
\text { teste de razoabilidade } \\
\text { - cláusula suprimida em } \\
\text { caso de fraude ou de- } \\
\text { claração falsa } \\
\text { - interpretação da cláu- } \\
\text { sula é feita em desfavor } \\
\text { de quem quer impor sua } \\
\text { aplicação (proferens) } \\
\text { - cláusula, para ser vá- } \\
\text { lida, deve passar por } \\
\text { testes de incorporação e } \\
\text { interpretação, além da } \\
\text { impossibilidade de sua } \\
\text { aplicação em caso de } \\
\text { fraude }\end{array}$ & $\begin{array}{l}\text { - distinção entre cláusu- } \\
\text { la de não indenizar e } \\
\text { cláusula de irresponsa- } \\
\text { bilidade, sendo o se- } \\
\text { gundo tipo nulo para } \\
\text { maioria da doutrina } \\
\text { - cláusula suprimida em } \\
\text { caso de má-fé do deve- } \\
\text { dor } \\
\text { - interpretação contra o } \\
\text { proferens também } \\
\text { - não pode ser afastada } \\
\text { responsabilidade por } \\
\text { morte ou lesão corporal, } \\
\text { em razão da dignidade } \\
\text { humana } \\
\text { - art. } 313 \text { do Código } \\
\text { Civil }\end{array}$ \\
\hline
\end{tabular}




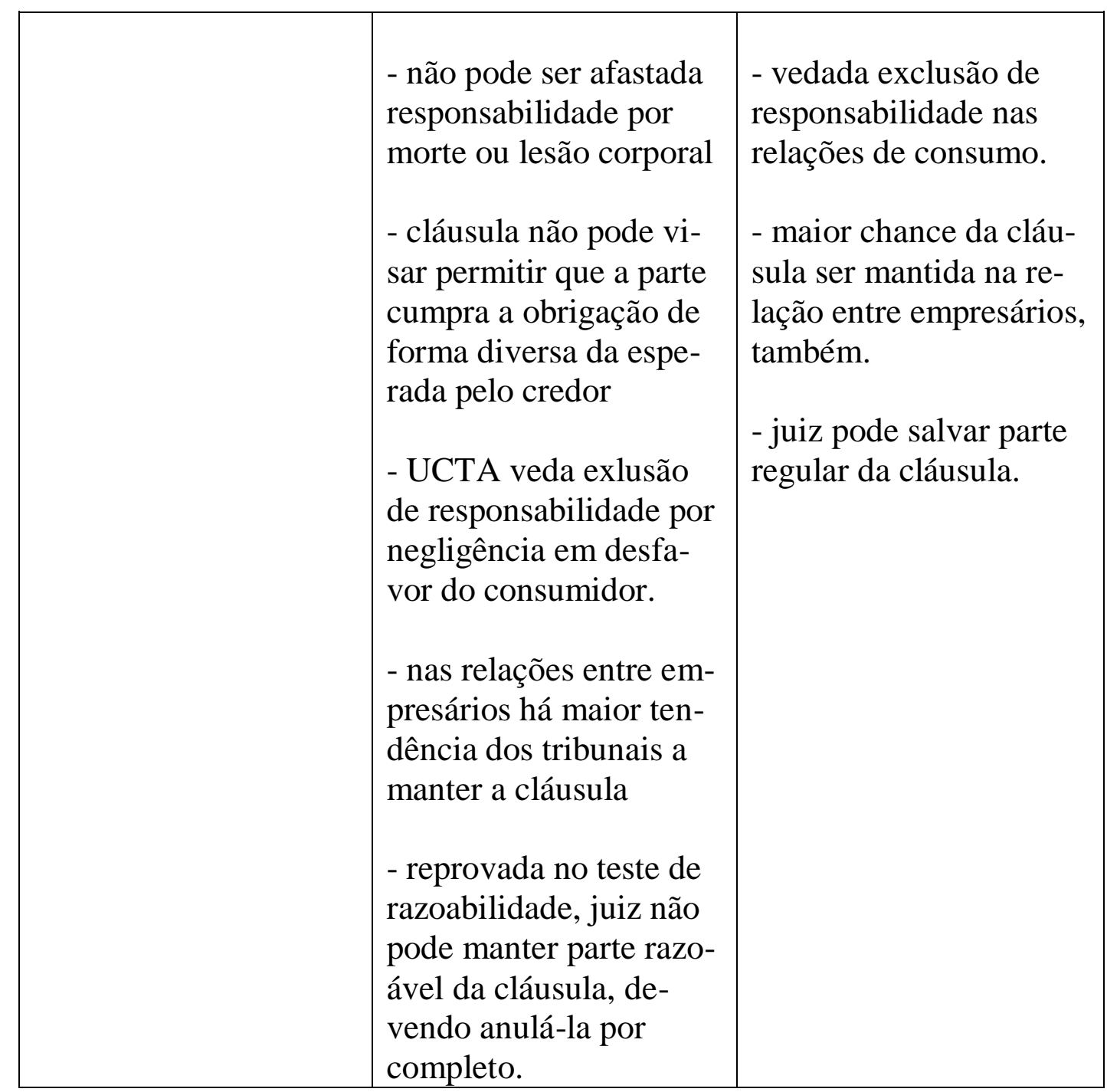

Fonte: Autoria própria. 


\section{CONCLUSÃO}

Ao longo desta análise comparativa foi possível concluir que os sistemas inglês e brasileiro guardam semelhanças quanto aos remédios jurídicos aplicáveis no inadimplemento contratual, mas também foram evidenciadas algumas diferenças, ora singelas, ora mais significativas, requerendo o olhar atento das partes contratantes.

Assim, externamos a nossa expectativa de que o presente trabalho possa ter concorrido para a identificação destes principais pontos de encontros e desencontros jurídicos entre os sistemas brasileiro e britânico quanto às soluções para o inadimplemento contratual, tema essencial à boa confecção e execução de todo contrato. 


\section{BIBLIOGRAFIA}

ANDREWS, Neil. Direito Contratual na Inglaterra. Tradução Teresa Arruda Alvim Wambier e Luana Pedrosa de Figueiredo Cruz. São Paulo: Editora Revista dos Tribunais, 2012.

ARAÚJO, Nadia de. Direito Internacional Privado: Teoria e Prática Brasileira. $5^{\text {a }}$ ed. Rio de Janeiro, Renovar, 2011.

ASHURST LLP. Limitation and Exclusion of Liability. 2009. Disponível em: https://www.ashurst.com/doc.aspx?id_Resource=4635. Acesso em: 08 nov 2014.

ATIYAH, Patrick. Law and Modern Society. Oxford University Press, 1989.

BODIN DE MORAES, Maria Celina, Danos à Pessoa Humana. Rio de Janeiro: Renovar, 2003.

CASTRO NEVES, José Roberto de. Direito das Obrigações. $2^{\mathrm{a}}$ ed. Rio de Janeiro: GZ Ed., 2009.

CAVALIERI FILHO, Sergio. Programa de Responsabilidade Civil. $6^{a}$ ed. São Paulo: Malheiros, 2005.

CRUISE, Rob. Penalty Clauses and Liquidated Damages: Traps for the Unwary. 2013. Disponível em: http://www.shoosmiths.co.uk/clientresources/Penalty-clauses-liquidated-damages-Traps-for-unwary4897.aspx. Acesso em: 13 nov 2014. 
DAVID, René. Os Grandes Sistemas de Direito Contemporâneo. $4^{\mathrm{a}}$ ed. São Paulo: Martins Fontes, 2002.

DAVID, René, English Law and French Law: A Comparison in Substance - Tagore Law Lectures. Londres: Stevens \& Sons, 1980.

FERNANDES, Paulo Campos e LEITÃO, Walter de Sá. Contratos de Afretamento à Luz dos Direitos Inglês e Brasileiro. Rio de Janeiro: Renovar, 2007.

LEHMEN, Alessandra. Specific Performance. 2003. Monografia de PósGraduação - Faculdade de Direito, Universidade Federal do Rio Grande do Sul. Disponível em: http://www.cbsg.com.br/pdf_publicacoes/specific performace.pdf. Acesso em: 18 out 2014 .

L.O. BAPTISTA, SCHMIDT, VALOIS, MIRANDA, FERREIRA, AGEL. Danos Acordados no Direito Comparado. Ano 6, nº 66, outubro 2010. Disponível em: http://www.baptista.com.br/news/Texto.aspx?Texto=394. Acesso em: 03 out 2014.

MADRUGA FILHO, Antenor Pereira. A Noção de Contrato na Common Law: Perspectiva Histórica. Revista de Informação Legislativa, Brasília, a. 36, $\mathrm{n}^{\mathrm{o}}$ 146, jul./set. 1999. Disponível em: http://www2.senado.leg.br/bdsf/bitstream/handle/id/518/r14319.PDF?sequence=4. Acesso em: 15 out 2014 .

McGREGOR, Harvey. McGregor on Damages. $19^{\mathrm{a}}$ ed. UK: Sweet \& Maxwell Ltd, 2014. 
NADER, Paulo. Curso de Direito Civil, volume 7: Responsabilidade Civil. $3^{\mathrm{a}}$ ed. Rio de Janeiro: Forense, 2010.

PEREIRA, Caio Mário da Silva. Instituições de Direito Civil: Volume II, Teoria Geral das Obrigações. 26ª ed. Rio de Janeiro: Forense, 2014.

PEREIRA, Caio Mário da Silva. Instituições de Direito Civil: Volume III, Contratos. 14 $4^{\mathrm{a}}$ ed. Rio de Janeiro: Forense, 2010.

PORTO, Sérgio Gilberto. Sobre a Common Law, Civil Law é o Precedente Judicial. Disponível em: http://www.abdpc.org.br/abdpc/artigos/sergio\%20porto-formatado.pdf. Acesso em 05 out 2014.

ROPPO, Enzo. O Contrato. Coimbra, Livraria Almedina, 1988.

TAVARES, Ana Lucia de Lyra. O Espírito da Common Law e os Contratos. Revista Brasileira de Direito Comparado, Rio de Janeiro, $n^{\circ} 18$, p. $23-$ $57,1^{\circ}$ semestre 2000. 